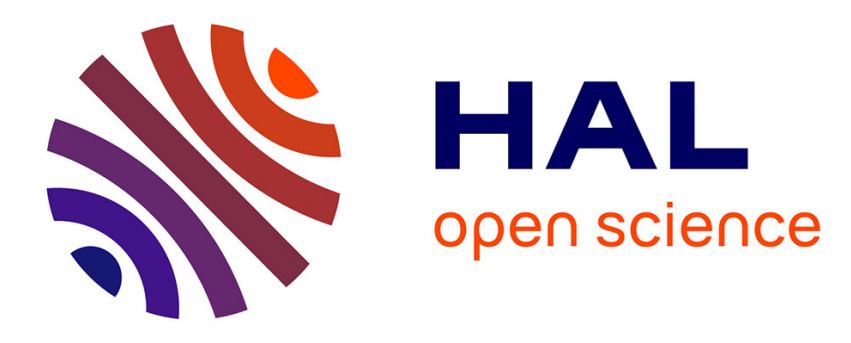

\title{
Dielectric-Barrier Discharges. Principle and Applications
}

\author{
U. Kogelschatz, B. Eliasson, W. Egli
}

\section{To cite this version:}

U. Kogelschatz, B. Eliasson, W. Egli. Dielectric-Barrier Discharges. Principle and Applications. Journal de Physique IV Proceedings, 1997, 07 (C4), pp.C4-47-C4-66. 10.1051/jp4:1997405 . jpa00255561

\section{HAL Id: jpa-00255561 https://hal.science/jpa-00255561}

Submitted on 1 Jan 1997

HAL is a multi-disciplinary open access archive for the deposit and dissemination of scientific research documents, whether they are published or not. The documents may come from teaching and research institutions in France or abroad, or from public or private research centers.
L'archive ouverte pluridisciplinaire HAL, est destinée au dépôt et à la diffusion de documents scientifiques de niveau recherche, publiés ou non, émanant des établissements d'enseignement et de recherche français ou étrangers, des laboratoires publics ou privés. 


\title{
Dielectric-Barrier Discharges. Principle and Applications
}

\author{
U. Kogelschatz, B. Eliasson and W. Egli
}

ABB Corporate Research Ltd., Baden, Switzerland

\begin{abstract}
Dielectric-barrier discharges (silent discharges) are non-equilibrium discharges that can be conveniently operated over a wide temperature and pressure range. At about atmospheric pressure electrical breakdown occurs in many independent thin current filaments. These short-lived microdischarges have properties of transient high pressure glow discharges with electron energies ideally suited for exciting or dissociating background gas atoms and molecules. The traditional application for large-scale ozone generation is discussed together with novel applications in excimer UV lamps, high power $\mathrm{CO}_{2}$ lasers and plasma display panels. Additional applications for surface treatment and pollution control are rapidly emerging technologies. Recent results on greenhouse gas recycling and utilisation in dielectric-barrier discharges are also discussed.
\end{abstract}

\section{INTRODUCTION}

Dielectric-barrier discharges (DBDs), also referred to as barrier discharges or silent discharges have for a long time been exclusively related to ozone generation. Detailed investigations into the properties of this non-equilibrium discharge which can be conveniently operated at about atmospheric pressure led to a number of new applications: The generation of powerful coherent infrared radiation in $\mathrm{CO}_{2}$ lasers and of incoherent VUV or UV excimer radiation in excimer lamps are two examples that became commercially available within a few years. Other processes like pollution control or surface treatment with DBDs show great promise for the future. As far as market potential is concerned the most important use of DBDs will be in ac plasma display panels. In 1996 multi-billion dollar investments in production facilities for largearea flat television screens in Japan and South Korea started a new age of large-scale industrial dielectric-barrier applications.

The most important characteristic of dielectric-barrier discharges is that non-equilibrium plasma conditions can be provided in a much simpler way than with other alternatives like low pressure discharges, fast pulsed high pressure discharges or electron beam injection. Its flexibility with respect to geometrical configuration, operating medium and operating parameters is unprecedented. Conditions optimised in laboratory experiments can easily be scaled up to large industrials installations. Efficient low cost power supplies are available up to very large powers.

First introduced by W. Siemens in 1857 [1] for the purpose of "ozonizing" air DBDs have for a long time been regarded as the ozonizer discharge. Important new insight into the structure of the discharge was gained by high voltage engineers studying gas breakdown. In 1932 Buss [2] observed that in a plane parallel gap with insulated electrodes air breakdown occurs in a number of individual tiny breakdown channels. More detailed information about these current channels was collected by Klemenc et al. in 1937 [3], by Honda and Naito in 1955 [4] and later by Gobrecht et al. [5], by Bagirov et al. [6], by Tanaka et al. [7], Hirth [8] and by Heuser [9].

More recently it was realised that the plasma parameters in these breakdown channels, now frequently referred to as microdischarges, can be influenced and modelled and consequently can be optimised for a given application [8,10-17]. Advanced plasma diagnostics and computer modelling has put $u$ s in a position to understand and tailor microdischarge properties for an intended purpose. Our present understanding of dielectric-barrier discharges is described starting with an overview of overall discharge characteristics and microdischarge properties. Ways of influencing microdischarge properties are discussed. Models of different degrees of sophistication are presented for computing plasma physical details about microdischarge formation during breakdown, plasma chemical reactions following breakdown, or both. A number of novel applications based on DBDs are described. 


\section{DISCHARGE STRUCTURE AND MICRODISCHARGE PROPERTIES}

Dielectric-barrier discharges are characterised by the presence of one or more insulating layers in the current path between metal electrodes in addition to the discharge space. Different planar or cylindrical configurations are common (Fig. 1). Closely related are surface discharge configurations in which discharges are initiated at a dielectric surface due to strong electric fields generated by imbedded metal electrodes. The presence of the dielectric(s) precludes dc operation. Although DBD configurations can be operated between line frequency and microwave frequencies the typical operating range for most technical DBD applications lies between $500 \mathrm{~Hz}$ and $500 \mathrm{kHz}$.
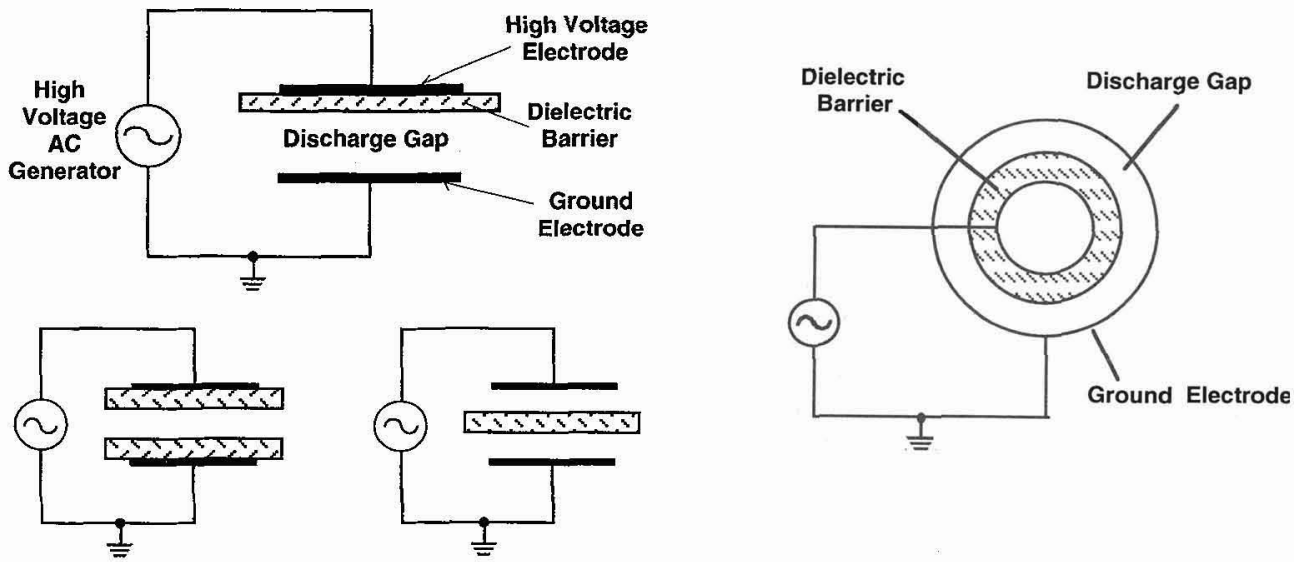

Fig. 1: Common dielectric-barrier discharge configurations

Gas spaces bounded by one or two dielectrics have practically the same breakdown voltage as if they were between metal electrodes. Typical clearances vary from less than $100 \mu \mathrm{m}$ to several $\mathrm{cm}$. For atmospheric pressure discharges gap spacings of a few $\mathrm{mm}$ are common thus requiring alternating driving voltages with amplitudes of typically $10 \mathrm{kV}$. Low loss dielectrics of high breakdown strength such as glass, quartz or ceramic plates or tubes are used to which metal electrode coatings can be applied. On the other hand, also metal electrodes with dielectric coatings, e. g. steel tubes with enamel layers can be used.

\subsection{Microdischarge Properties}

The most interesting property of DBDs is that in most gases at about atmospheric pressure breakdown is initiated in a large number of independent current filaments or microdischarges. Fig. 2 shows a snapshot of such microdischarges in a $1 \mathrm{~mm}$ air gap photographed through a transparent electrode.

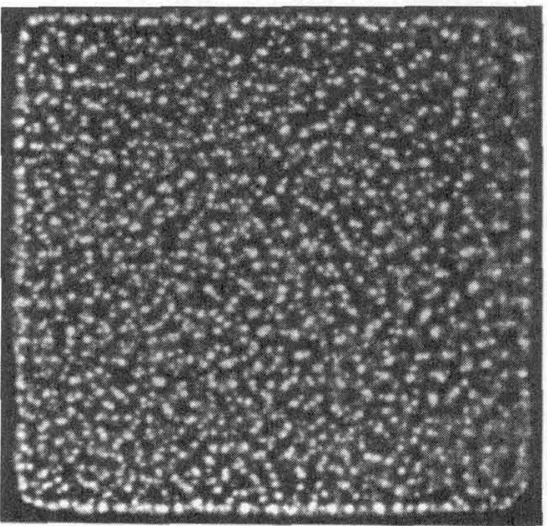

Fig. 2: End-on view of microdischarges Original size: $6 \times 6 \mathrm{~cm}$, exposure time: $20 \mathrm{~ms}$

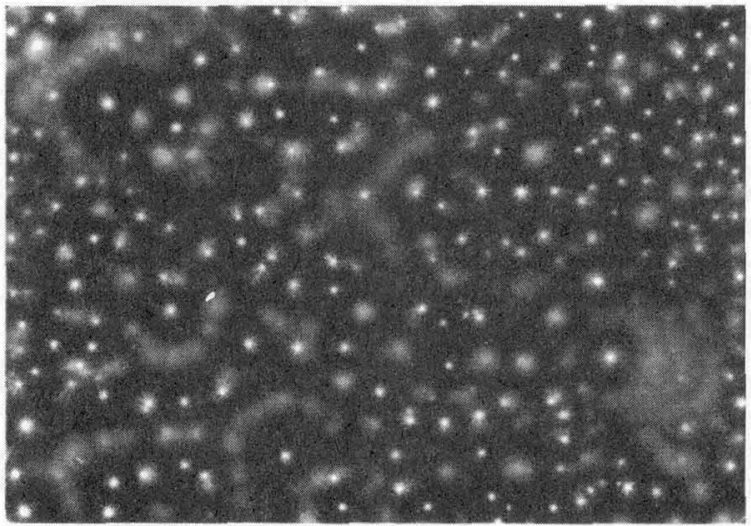

Fig. 3: Lichtenberg figure showing footprints of individual microdischarges, original size: $7 \times 10 \mathrm{~cm}$ 
Fig. 3 shows footprints of individual microdischarges left on a photographic plate with the emulsion facing the discharge gap and the glass plate serving as the dielectric. After applying a high voltage halfwave the plate was developed in the dark room. This photographic technique had already been used by Buss [2] in 1932 who found that we can expect about 10 microdischarges of submicrosecond duration per $\mathrm{cm}^{2}$ and that the channel diameter is roughly $0.1 \mathrm{~mm}$. These findings are in accordance with later more sophisticated measuring and modelling techniques.

At the dielectric surface a microdischarge channel spreads into a surface discharge covering a region much larger than the original channel diameter. Typical microdischarge properties (order of magnitude) for a $1 \mathrm{~mm}$ air gap at 1 bar can be summarised as follows:

Table 1: Characteristic Microdischarge Properties.

\begin{tabular}{|ll|ll|}
\hline Duration: & $1-10 \mathrm{~ns}$ & Total Charge: & $0.1-1 \mathrm{nC}$ \\
Filament Radius: & about $0.1 \mathrm{~mm}$ & Electron Density: & $\begin{array}{l}10^{14}-10^{15} \mathrm{~cm}^{-3} \\
\text { Peak Current }\end{array}$ \\
$\begin{array}{l}\text { Electron Energy: } \\
\text { Current Density: }\end{array}$ & $\begin{array}{l}\text { Gas Temperature: } \\
\text { close to average gap } \\
\text { temperature }\end{array}$ \\
\hline
\end{tabular}

The microdischarge filaments can be characterised as weakly ionised plasma channels with properties resembling those of transient high pressure glow discharges. They ignite when the breakdown field is reached and extinguish not far below the same field value when electron attachment and recombination reduce plasma conductivity. Due to charge build up on the dielectric the field at the location of a microdischarge is reduced within a few ns after breakdown thus terminating the current flow at this location. Detailed measurements about microdischarge properties have been performed [8-10,14,18-21]. The transported charge is proportional to the gap spacing and the permittivity of the dielectric but does not depend on pressure. The current density in a microdischarge channel can reach 100 to $1000 \mathrm{Acm}^{-2}$. Due to the short duration this normally results in very little transient gas heating in the remaining channel. Humidity tends to increase the strength of a microdischarge while irradiating the cathode with UV photons tends to decrease it. The dielectric barrier limits the amount of charge and energy deposited in a microdischarge and distributes the microdischarges over the entire electrode surface. As long as the external voltage is rising additional microdischarges will occur at new positions because the presence of residual charges on the dielectric has reduced the electric fields at positions where microdischarges have already occurred. When the voltage is reversed, however, the next microdischarges will form in the old microdischarge locations. So, high voltage low frequency operation tends to spread the microdischarges, while low voltage high frequency operation tends to reignite the old microdischarge channels every half period. This memory effect due to charge deposition on the dielectrics is extensively used in ac plasma displays.

Over a wide range of operating frequencies and voltage shapes microdischarge properties do not depend on the external driving circuit. They are determined by the gas properties, the pressure and the electrode configuration. Raising the powèr for a given configuration means generating more microdischarges per unit of time and/or per unit of electrode surface area. This characteristic of DBDs is very important because it allows us to investigate and optimise microdischarge properties for a given application in a fairly small laboratory set-up. Scale-up even to very large electrode surfaces in industrial applications normally does not present a problem if gap spacing and power density is not changed.

Individual microdischarge properties can however be changed for a given configuration when extremely fast rising voltages are applied. When the rise time of the voltage becomes comparable to the duration of a microdischarge a large number of microdischarges may be started simultaneously. In this case there may not be enough surface area available on the dielectric to accommodate all surface discharges of the initiated microdischarges. As a consequence weaker microdischarges result. The pulsed DBD mode offers additional flexibility by synchronising the microdischarges, by overshooting the stationary breakdown voltage and by adapting the pauses between pulses in accordance with the process under investigation.

\subsection{Overall Discharge Characteristics}

The described uniformity of individual microdischarges leads to a well defined overall discharge behaviour. This can be shown, for example, by recording voltage/charge Lissajous figures (Fig. 4). Suppose we apply a sinusoidal voltage. Initially, without discharge, the total capacitance $\mathrm{C}_{\mathrm{tot}}$ is charged with rising voltage. When the breakdown voltage of the gas space is reached microdischarges occur that start to charge the capacitance of the dielectric $C_{D}$ while the discharge voltage $U_{D i s}$, the average voltage 
across the gas space, remains constant. This stops when the maximum of the voltage $\hat{\mathrm{U}}$ is reached and the reverse situation occurs in the second half wave. In many DBD applications the voltage/charge Lissajous figure is an almost ideal parallelogram (oscillogram in Fig. 4). From the slopes the effective capacitances $C_{t o t}$ and $C_{D}$ can be derived, and $U_{M i n}$ and $\hat{U}$ can be immediately determined [22]. The form of the voltage/charge Lissajous figure is independent of the form of the applied voltage as, long as the notion of a constant discharge voltage holds. The enclosed area is always proportional to the power independent of such assumptions. According to Müller and Zahn [23] DBDs can exhibit different modes depending on the gas and the operating conditions.

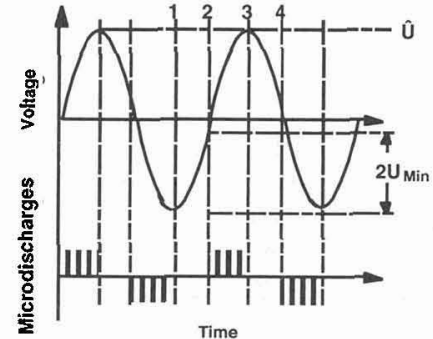

a

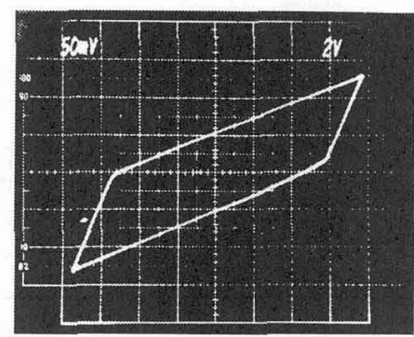

b

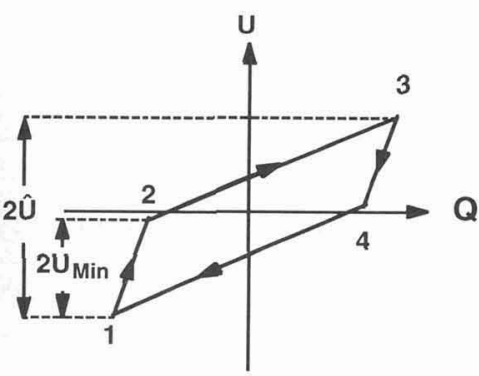

c

Fig. 4: Schematic diagram of applied voltage and microdischarge activity (a) and recorded (b) and schematic representation (c) of voltage/charge Lissajous figure

From voltage/charge diagrams Manley in 1943 [24] derived the power formula for ozonizers which applies to many DBDs. The enclosed area corresponds to the energy dissipated during one period of the applied voltage. According to Manley the total power is given by:

$$
P=4 \mathrm{fC}_{\mathrm{D}} \mathrm{U}_{\text {Dis }}\left\{\hat{\mathrm{U}}-\mathrm{C}_{\mathrm{D}}^{-1}\left(\mathrm{C}_{\mathrm{D}}+\mathrm{C}_{\mathrm{g}}\right) \mathrm{U}_{\text {Dis }}\right\}, \hat{\mathrm{U}} \geq \mathrm{C}_{\mathrm{D}}^{-1}\left(\mathrm{C}_{\mathrm{D}}+\mathrm{C}_{\mathrm{g}}\right) \mathrm{U}_{\text {Dis }}
$$

where $f$ is the frequency and $C_{g}$ the capacitance of the discharge gap. Since the fictitious discharge voltage $U_{\text {Dis }}$ cannot be measured directly, it is sometimes advantageous to express the power $P$ by measurable quantities [22].

$$
P=4 \mathrm{f} \mathrm{C}_{\mathrm{D}}{ }^{2}\left(\mathrm{C}_{\mathrm{D}}+\mathrm{C}_{\mathrm{g}}\right)^{-1} \mathrm{U}_{\text {Min }}\left(\hat{\mathrm{U}}-\mathrm{U}_{\text {Min }}\right), \quad \hat{\mathrm{U}} \geq \mathrm{U}_{\text {Min }}
$$

where $U_{M i n}$ is the minimum external voltage required to maintain a discharge. The voltages are related by $\mathrm{U}_{\text {Dis }}=\mathrm{C}_{\mathrm{D}}\left(\mathrm{C}_{\mathrm{D}}+\mathrm{C}_{\mathrm{g}}\right)^{-1} \mathrm{U}_{\text {Min }}$.

The applied voltage/charge Lissajous figure and corresponding gap voltage/current presentations are very useful instruments for characterising the discharge behaviour and designing power supplies and matching circuits. Tanaka and co-workers have extensively used these tools to characterise different modes of dielectric-barrier discharges $[25,26]$. At very high operating frequencies, e. g. a $10 \mathrm{MHz}$ sine wave, or also for wide gaps at reduced pressure, the parallelogram of Fig. 4 turns into an ellipse, indicating that plasma conductivity no longer decays between successive halfwaves. The voltage/charge Lissajous figure of a plasma display panel driven by a $100 \mathrm{kHz}$ square wave, on the other hand, shows a well defined jump of the charge whenever an applied voltage of $\pm 200 \mathrm{~V}$ is reached [26].

\section{MODELLING DIELECTRIC-BARRIER DISCHARGES}

\subsection{Modelling of the Reaction Kinetics}

Different aspects of dielectric barrier discharge modelling can be addressed. For a rough determination of the different time constants involved it is often convenient to disregard spatial gradients in the beginning and treat a homogeneous plasma as a first step. To simulate the action of a short-lived microdischarge either a short high voltage pulse is applied $[10,12]$ or an electron beam is injected $[27,28]$. In both cases it is necessary to derive the rate coefficients for electron impact collisions in the gas mixture under consideration by solving the Boltzmann equation. This requires a reliable set of electron collision cross sections. For DBD calculations the local field approximation is normally used, assuming that the electron energy distribution is in equilibrium with the electric field and that all rate coefficients can be tabulated as a sole function of the mean electron energy or the reduced field E/n.

Although these assumptions appear rather crude they have been used extensively and rather successfully in optimising ozone generators. The physical reason for this success is as follows. At atmospheric pressure electrons accelerated in the electric field perform so many collisions with the background gas that they approach equilibrium values within about 10 ps. Appreciable voltage changes 
and corresponding electric field changes are much slower, typically in the ns range. So, in many cases it is justified to work with stationary solutions of the Boltzmann equation. Excitation and dissociation by electron collision are again extremely fast processes followed by free radical reactions that occur at an intermediate time scale, typically 1 to $100 \mu \mathrm{s}$ at atmospheric pressure. Most free radical reactions will therefore be completed before any substantial displacement of the involved species by diffusion or convection can take place. These processes take much longer and occur at ms time scales. So, in many cases where the final product is formed essentially by free radical reactions, simulating what happens within the microdischarge filament can give already a fairly good approximation. In simulating the action of many microdischarges in complicated gas mixtures a first approach neglecting the electron kinetics may also be to repetitively inject certain concentrations of free radicals and then compute the following chemical reactions $[13,29]$. This approach is normally taken if reliable electron collision cross sections are missing for some components of the gas mixture under consideration.

\subsection{Two-Dimensional Modelling}

Modelling microdischarge formation is closely related to computing gas breakdown at atmospheric pressure. In the early phases of discharge development there is little difference between breakdown between metal electrodes and breakdown in a gap with one or two dielectric walls. When an overvoltage is applied to a discharge gap at atmospheric pressure an electron avalanche starting at the cathode soon reaches a critical stage where the local "eigenfield" caused by space charge accumulation at the avalanche head leads to a situation where extremely fast streamer propagation towards both electrodes becomes possible. Breakdown between metal electrodes was treated by Kline and Siambis [30], Lozanskii [31, 32], Gallimberti [33], Kunhardt et al. [34 - 35], Marode and co-workers [36], Dhali and Williams [37, 38], Yoshida and Tagashira [39] and more recently also by Kulikovsky [40] and by Babaeva and Naidis [41], among others. Computations of propagating streamers in atmospheric air and $\mathrm{SF}_{6}$ were also presented by Morrow and Lowke [42-44] and very detailed numerical investigations about streamer morphology in nitrogen were published by Vitello and co-workers. [45]. All these computations come to the conclusion that extremely high electric fields occur at the streamer head, that a reasonably thin conductive channel (diameter of the order $100 \mu \mathrm{m}$ ) is formed with maximum electron densities in the range $10^{14}$ to $10^{15} \mathrm{~cm}^{-3}$. Propagation is caused by ionisation waves travelling at a speed much higher than the electron drift velocity.
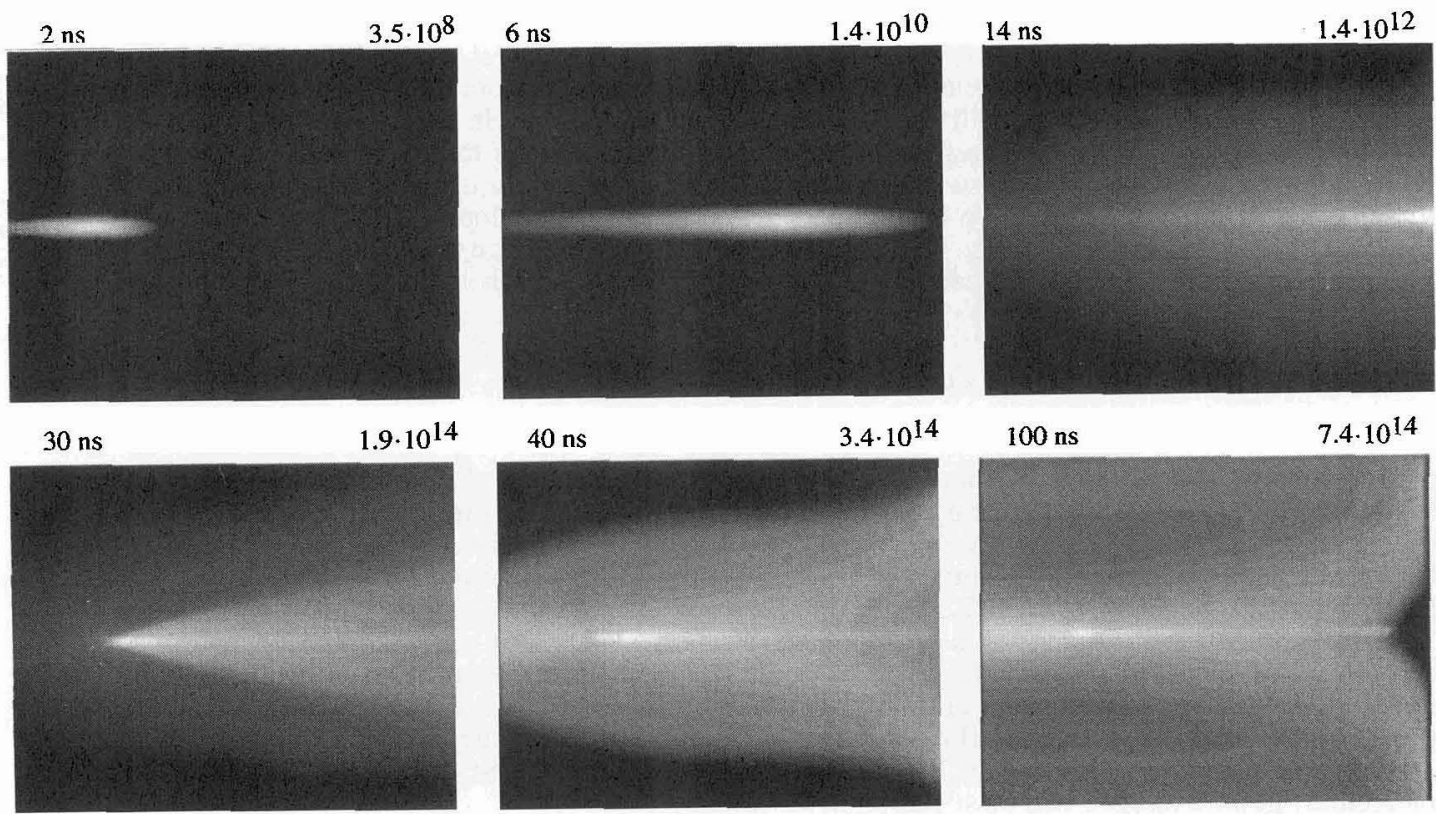

$100 \mathrm{~ns}$

$7.4 \cdot 10^{14}$

Fig. 5: Development of a microdischarge in an atmospheric pressure $\mathrm{H}_{2} / \mathrm{CO}_{2}$ mixture (4/1). The $1 \mathrm{~mm}$ discharge gap is bounded by a plane metal cathode (left) and a $0.8 \mathrm{~mm}$ thick dielectric of $\varepsilon=3$ (right). A constant voltage is applied, that results in an initially homogeneous reduced field of $125 \mathrm{Td}$ in the gas space which corresponds to an overvoltage of $90 \%$ in this mixture. The numbers in the right upper corner indicate the maximum electron density in $\mathrm{cm}^{-3}$ reached in that picture. The maximum current of $35 \mathrm{~mA}$ is reached at $40 \mathrm{~ns}$. 
Numerical simulation of microdischarge formation in a gap bounded by a dielectric has to include the process of charge accumulation on the dielectric surface. As a consequence of this deposited charge the electric field in the gap is reduced and the microdischarge is choked, typically within a few ns. This process has been extensively studied in connection with ozone research [12,15,46-50]. These calculations show that upon arrival of the cathode directed streamer within a fraction of a ns a cathode layer is formed with extremely high reduced fields of several thousand $\mathrm{Td}$. In air at atmospheric pressure the thickness of this cathode layer is about $10 \mu \mathrm{m}$ and the current density at its outer boundary is about $250 \mathrm{~A} \mathrm{~cm}^{-2}$. For a $1 \mathrm{~mm}$ air gap the maximum current of 0.1 A peaks at the time of the cathode layer formation. At this time a conductive channel of about $200 \mu \mathrm{m}$ radius is established which expands in front of the dielectric barrier. The current then decays due to charge accumulation on the dielectric surface where a maximum charge density of about $20 \mathrm{nC} \mathrm{cm}^{-2}$ is found. The total energy dissipated by the microdischarge amounts to about $5 \mu \mathrm{J}$ leading to mean overtemperature in the column of about $5 \mathrm{~K}$ only [15]. In recent years such $2 \mathrm{D}$ models have also been applied to other gases like xenon [12], carbon dioxide [13,29] or combustion flue gases $[16,51]$.

\section{OZONE GENERATION}

\subsection{Properties and Applications of Ozone}

For industrial purposes ozone is exclusively generated in large installations using dielectric-barrier discharges $[22,52]$. Ozone is a potent germicide and one of the strongest known oxidants. In many applications it can replace chlorine thus causing less environmental concern. Because ozone is only moderately stable it will eventually decay to form $\mathrm{O}_{2}$ or, in the presence of organic substances, perhaps $\mathrm{CO}_{2}$. In the absence of oxidisable substances this decay occurs within a few days. Elevated temperatures, ultraviolet radiation, or the presence of catalysts accelerate ozone destruction considerably. Although ozone itself is toxic, ozone treatment leaves no toxic residues that have to be treated or disposed of.

Ozone has a characteristic pungent odour and is a practically transparent colourless gas. In the ultraviolet spectral region, however, it exhibits extremely strong absorption peaking around $250 \mathrm{~nm}$ (Hartley band). This property is responsible for the strong filtering action of the stratosphere. The ozone layer, which apparently is endangered by anthropogenic emissions, protects the biosphere against dangerous short-wavelength radiation from the sun.

The traditional application of ozone is for water treatment which has a long tradition especially in Europe. About one hundred years ago it was realised that the germicidal and viricidal effects of ozone can provide safe drinking water in areas previously endangered by cholera and typhus epidemics. The first major ozone installations went into operation in Nice in 1907 and in St. Petersburg in 1910. Although up to recently many countries have preferred chlorine chemistry for water treatment because of its lower cost there is a strong tendency now to switch to ozone. The main targets for using ozone in water treatment are disinfection, control of disinfection by-products (trihalomethanes), colour, taste, odours, pesticides or the removal of iron and/or manganese. The second important growing large-scale use of ozone is in the paper industry. By combining oxygen, ozone and hydrogen peroxide bleaches, pulp can be treated in a closed circuit without using chlorine.

\subsection{Plasma Chemistry of Ozone Formation}

As mentioned above many investigations on dielectric-barrier discharges in general and especially on microdischarge properties were motivated by research activities aimed at improving ozone generation. Many of the very extensive Russian contributions to this subject are summarised in the (Russian) books by Filippov et al. 1987 [53] and by Samoilovich et al. 1989 [54]. Overviews of the historical aspects and the physics and chemistry involved have been given in some review papers and handbook articles by Eliasson and Kogelschatz [12,13,22,55-57].

Local electrical breakdown in narrow discharge gaps leads to microdischarge formation and short current pulses. Detailed calculations of the elctronic and ionic processes and the following neutral particle reactions in oxygen as well as in air show that mainly the electrons are important for ozone formation $[10,14]$. So one of the secrets of efficient ozone generation is to generate microdischarges with negligible energy losses to ions. The role of the electrons is then to excite and dissociate oxygen and nitrogen molecules. In pure oxygen two dissociation path ways are available:

$$
\begin{aligned}
\mathrm{e}+\mathrm{O}_{2} & \Rightarrow \mathrm{e}+\mathrm{O}_{2}\left(\mathrm{~A}^{3} \Sigma_{\mathrm{u}}^{+}\right) \Rightarrow \mathrm{e}+\mathrm{O}\left({ }^{3} \mathrm{P}\right)+\mathrm{O}\left({ }^{3} \mathrm{P}\right) \\
& \Rightarrow \mathrm{e}+\mathrm{O}_{2}\left(\mathrm{~B}^{3} \Sigma_{\mathrm{u}}\right) \Rightarrow \mathrm{e}+\mathrm{O}\left({ }^{3} \mathrm{P}\right)+\mathrm{O}\left({ }^{\prime} \mathrm{D}\right)
\end{aligned}
$$


with energy thresholds of $6 \mathrm{eV}$ and $8.4 \mathrm{eV}$, respectively. In air naturally also nitrogen molecules are subjected to electron collisions which results in excitation and subsequent energy transfer to $\mathrm{O}_{2}$ molecules or direct dissociation and subsequent reaction:

$$
\begin{aligned}
\mathrm{e}+\mathrm{N}_{2} & \Rightarrow \mathrm{e}+\mathrm{N}_{2}\left(\mathrm{~A}^{3} \Sigma_{\mathrm{u}}^{+}\right) \\
& \Rightarrow \mathrm{e}+\mathrm{N}_{2}\left(\mathrm{~B}^{3} \Pi_{\mathrm{u}}\right) \\
\mathrm{N}_{2} *(\mathrm{~A}, \mathrm{~B})+\mathrm{O}_{2} & \Rightarrow \mathrm{N}_{2}+2 \mathrm{O} \\
& \Rightarrow \mathrm{N}_{2} \mathrm{O}+\mathrm{O}
\end{aligned}
$$

$$
\begin{aligned}
& \mathrm{e}+\mathrm{N}_{2} \Rightarrow \mathrm{e}+2 \mathrm{~N} \\
& \mathrm{~N}+\mathrm{O}_{2} \Rightarrow \mathrm{NO}+\mathrm{O} \\
& \mathrm{N}+\mathrm{NO} \Rightarrow \mathrm{N}_{2}+\mathrm{O}
\end{aligned}
$$

These reactions show that part of the energy lost in collisions with nitrogen molecules can be utilised for the generation of oxygen atoms and second that NO formation cannot be avoided [58]. As a matter of fact, in air roughly half the ozone concentration of that in pure oxygen is obtained. The electron kinetics in oxygen and air has been treated by several authors [58 - 66]. Also its application to DBDs has been treated $[10,12,14,15,54,56,67]$. Ozone is formed almost exclusively from oxygen atoms, a process which, at atmospheric pressure, takes about $10 \mu \mathrm{s}$ in oxygen and about $100 \mu \mathrm{s}$ in air.

$$
\mathrm{O}+\mathrm{O}_{2}+\mathrm{M} \Rightarrow \mathrm{O}_{3}+\mathrm{M}
$$

Computations at low ozone concentrations predict maximum efficiencies of slightly over $30 \%$ in pure oxygen and roughly half of that in air. Based on the enthalpy of formation of $1.48 \mathrm{eV}$ per $\mathrm{O}_{3}$ molecule $100 \%$ efficiency corresponds to a yield of 0.68 ozone molecules $/ \mathrm{eV}$ or $1.22 \mathrm{~kg} / \mathrm{kWh}$. The optimum reduced field for ozone formation in oxygen is about $140 \mathrm{Td}$ in pure oxygen and closer to $200 \mathrm{Td}$ in air $[10,14,55]$.

Microdischarge properties can be tailored by optimising operating pressure, gap spacing and the dielectric barrier. If the microdischarges get too strong recombination of oxygen atoms reduces the chemical efficiency of ozone formation. At $1 \%$ atom concentration, for example, every second oxygen atom recombines to $\mathrm{O}_{2}$ instead of forming $\mathrm{O}_{3}$. If the microdischarges are too weak, on the other hand, energy losses to ions become important. A reasonable compromise in oxygen is found when the degree of dissociation in the microdischarge channel reaches about $0.2 \%$ : The corresponding current density peaks at about $500 \mathrm{Acm}^{-2}$, a current density at which the electron component dominates and energy losses by ions can be neglected. In oxygen about $80 \%$ of the energy transferred to electrons can be utilised for the dissociation of $\mathrm{O}_{2}[10,22]$.
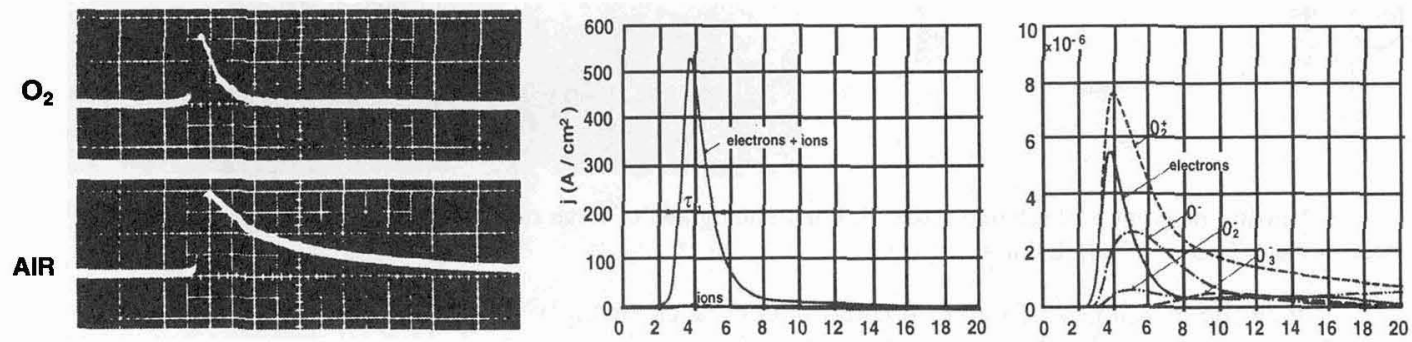

Time: $2 \mathrm{~ns} / \mathrm{small}$ div.

Ampl.: $40 \mathrm{~mA} /$ small div.

Time (ns)

Time (ns)

Fig. 6: Measured microdischarge current pulses in $\mathrm{O}_{2}$ and air, simulated total and ion current density and charged particle concentrations in $\mathrm{O}_{2}$

\subsection{Nitrogen Oxide Formation}

Since the $\mathrm{N}_{\mathrm{x}} \mathrm{O}_{\mathrm{y}}$ reaction kinetics has recently again attracted attention in connection with plasma remediation of flue gases a few facts about air fed in ozonizers shall be briefly mentioned. At the output of an ozone generator in the presence of ozone only the highest oxidation state $\mathrm{N}_{2} \mathrm{O}_{5}$ is detected together with traces of the fairly inert nitrous oxide $\mathrm{N}_{2} \mathrm{O}$ [68]. $\mathrm{N}_{2} \mathrm{O}$ results from a reaction of excited $\mathrm{N}_{2}{ }^{*}(\mathrm{~A})$ with $\mathrm{O}_{2}$ at early times during discharge development [63]. $\mathrm{N}_{2} \mathrm{O}_{5}$ is formed in slow reactions from the intermediate species $\mathrm{NO}_{2}$ and $\mathrm{NO}_{3}$ if no water vapour is present. Otherwise $\mathrm{HNO}_{3}$ is formed. If the power density or the temperature is raised $\mathrm{N}_{\mathrm{x}} \mathrm{O}_{\mathrm{y}}$ concentrations increase and ozone production decreases. When the $\mathrm{N}_{\mathrm{x}} \mathrm{O}_{\mathrm{y}}$ reach a certain level ozone generation breaks down completely, an effect which has been referred to as "discharge poisoning". The reason is a catalytic reaction cycle also known from stratospheric chemistry: 


$$
\begin{array}{ll}
\mathrm{O}+\mathrm{NO}+\mathrm{M} & \Rightarrow \mathrm{NO}_{2}+\mathrm{M} \\
\mathrm{O}+\mathrm{NO}_{2} & \Rightarrow \mathrm{NO}+\mathrm{O}_{2} \\
\hline \mathrm{O}+\mathrm{O} & \Rightarrow \mathrm{O}_{2}
\end{array}
$$

The left cycle leads to enhanced "catalytic" recombination of oxygen atoms, the right cycle results in enhanced ozone destruction. The effect can easily be demonstrated with an ozone generator operating on dry air or oxygen. If as little as $0.1 \% \mathrm{NO}$ or $\mathrm{NO}_{2}$ is added to the feed gas ozone production breaks down completely $[8,22,52,55,69,70]$.

\subsection{Industrial Ozone Generation}

Most technical ozone generators make use of cylindrical discharge tubes of about 20-50 mm diameter and 1-2 m length. Glass tubes are mounted inside stainless steel tubes to form a narrow annular discharge space (Fig. 7). The high voltage electrode is formed by a conductive coating, e.g. a thin aluminium film on the inside of the glass tubes. The preferred dielectric material is borosilicate glass (Pyrex, Duran). In advanced ozone generators also layered enamel coatings with optimised dielectric characteristics are used on steel tubes. Large ozone generators use several hundred tubes and produce up to $100 \mathrm{~kg}$ ozone per hour.
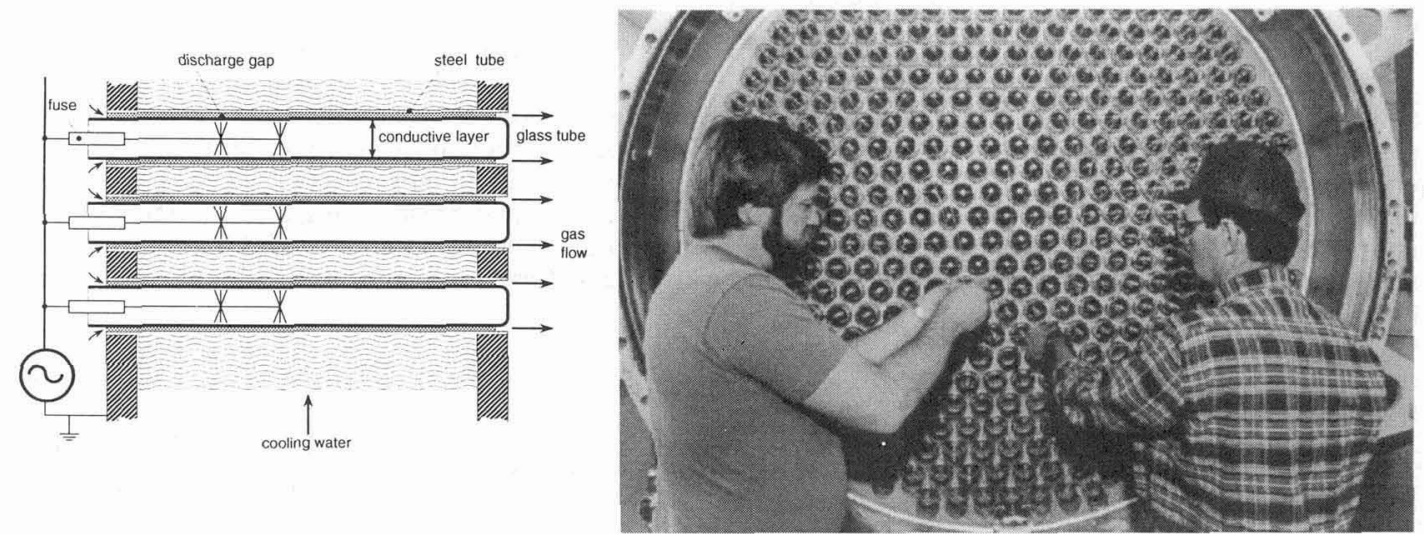

Fig. 7: Schematic diagram of discharge tubes [52] and photograph of large ozone generator at the Los Angeles Aqueduct Filtration Plant (Courtesy K. L. Rakness)

Since the efficiency of ozone formation decreases strongly with rising temperature modern ozone generators use narrow discharge gaps to ensure efficient heat removal. Typical gap spacings are in the range of 0.5 to $2 \mathrm{~mm}$. Recently also extremely narrow gaps of $0.1 \mathrm{~mm}$ width have been proposed. The average increase of gas temperature $\Delta \mathrm{T}_{\mathrm{g}}$ is determined by a balance of the discharge power not used for ozone formation - unfortunately the major part - and heat removal by radial heat conduction to the cooled steel electrode[10,22,52]

$$
\Delta \mathrm{T}_{\mathrm{g}}=\frac{1}{3} \frac{\mathrm{d}}{\lambda} \frac{\mathrm{P}}{\mathrm{F}}(1-\eta)
$$

where $\mathrm{d}$ is the gap spacing, $\lambda$ the heat conductivity of the feed gas, $\mathrm{P} / \mathrm{F}$ the power density referred to the electrode area and $\eta$ the efficiency of ozone generation. If the power, on a time average, is evenly dissipated in the gap volume the resulting radial temperature profile is a half parabola with its peak value at the (uncooled) glass tube. The wall temperature $T_{W}$ of the steel tube is determined by the cooling water. The average temperature in the discharge gap is given by

$$
\mathrm{T}_{\mathrm{g}}=\mathrm{T}_{\mathrm{W}}+\Delta \mathrm{T}_{\mathrm{g}}=\mathrm{T}_{\mathrm{W}}+\frac{1}{3} \frac{\mathrm{d}}{\lambda} \frac{\mathrm{P}}{\mathrm{F}}(1-\eta)
$$

With typical values for the operating parameters $\left(\mathrm{T}_{\mathrm{W}}=20^{\circ} \mathrm{C}, \mathrm{d}=2 \times 10^{-3} \mathrm{~m}, \lambda=2.5 \times 10^{-2} \mathrm{~W} / \mathrm{mK}, \mathrm{P} / \mathrm{F}=\right.$ $2 \mathrm{~kW} / \mathrm{m}^{2}, \eta=10 \%$ ) we arrive at an average temperature of about $70^{\circ} \mathrm{C}$ in the gap. The peak value at the glass tube reaches approximately $90^{\circ} \mathrm{C}$. According to eq. (20) lowering $\mathrm{T}_{\mathrm{W}}$ and using narrower discharge 
gaps will reduce the gas temperature. The most effective way of cooling the gap is the introduction of a second cooling circuit for the glass tubes which would reduce $\Delta T_{g}$ by a factor of four. Since this requires cooling of the high voltage electrode it is rarely done in technical ozone generators.

Traditionally, ozone generators were operated at line frequency. For smaller low cost ozone installations this technique is still used. Modern high-power ozone generators use thyristor-controlled frequency converters generating square wave currents at frequencies between 0.5 and $5 \mathrm{kHz}$. This way power levels up to $1 \mathrm{MW} /$ unit can be handled.

\section{INCOHERENT EXCIMER ULTRAVIOLET SOURCES}

As mentioned earlier the plasma in a microdischarge can be characterised as a transient high pressure glow discharge. When a dielectric-barrier discharge is operated in rare gases or a rare gas/halogen mixture plasma conditions in a microdischarge channel are similar to those in pulsed excimer lasers. As a consequence each microdischarge can act as an intense source of ultraviolet (UV) or vacuum ultraviolet (VUV) radiation. Excimer formation is favoured by high collision rates requiring a high pressure and efficient excitation or ionisation of precursor species which requires a non-equilibrium discharge. DBDs conveniently combine these two requirements. Typical examples are the formation of $\mathrm{Xe}_{2}{ }^{*}$ or $\mathrm{XeCl}^{*}$ excimer complexes, one of which is formed essentially from neutral excited atoms the other mainly via recombination of ions. The most important reactions are [11]:

$$
\begin{aligned}
& \mathrm{e}+\mathrm{Xe} \Rightarrow \mathrm{e}+\mathrm{Xe}^{*}\left({ }^{3} \mathrm{P}_{1,2}\right) \\
& \mathrm{Xe}+\mathrm{Xe}^{*}+\mathrm{M} \Rightarrow \mathrm{Xe}_{2}{ }^{*}\left({ }^{1} \Sigma_{\mathrm{u}}+{ }^{3} \Sigma_{\mathrm{u}}^{+}\right)+\mathrm{M} \\
& \mathrm{Xe}_{2}{ }^{*} \Rightarrow \mathrm{Xe}+\mathrm{Xe}+\mathrm{VUV} \text { radiation }
\end{aligned}
$$

$$
\begin{aligned}
& \mathrm{e}+\mathrm{Xe} \Rightarrow \mathrm{e}+\mathrm{Xe}^{+}, \mathrm{e}+\mathrm{Cl}_{2} \Rightarrow \mathrm{Cl}^{-}+\mathrm{Cl} \\
& \mathrm{Xe}^{+}+\mathrm{Cl}^{-} \Rightarrow \mathrm{XeCl}^{*} \\
& \mathrm{XeCl}^{*} \Rightarrow \mathrm{Xe}+\mathrm{Cl}+\mathrm{UV}(308 \mathrm{~nm})
\end{aligned}
$$

\subsection{Typical Excimer Lamp Configurations and Gas Mixtures}

When these gases are filled in quartz vessels whose walls act as dielectric barriers and transparent or perforated electrodes are applied excimer lamps can be built [11,72-75]. Fig. 8 shows a water cooled cylindrical version and a planar configuration. These lamps can be operated at high power densities using gap spacings of a few $\mathrm{mm}$, voltages of a few $\mathrm{kV}$ and frequencies of a few hundred kHz. Reliable switchmode power supplies can be matched to the characteristics of the discharge to reach plug efficiencies of $90 \%$ regarding the energy deposited in the plasma. In a practical device typically $5-15 \%$ of the discharge power can be converted to UV or VUV radiation.

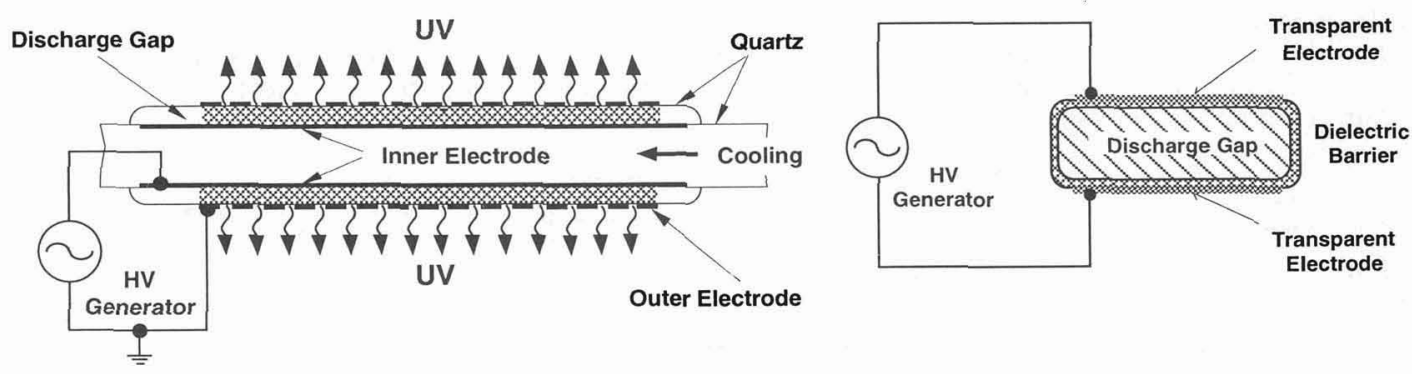

Fig. 8.: Cylindrical and planar excimer UV lamp configurations [73]

A large variety of excimer forming gas mixtures have successfully been tried out. Fig. 9 shows six representative excimer lamp spectra all of which show extremely clean spectra with narrow-band excimer emission in only one wavelength region.

The xenon excimer spectrum in Fig. 9 shows the emission of the second excimer continuum peaking around $172 \mathrm{~nm}$. Its width at half intensity is $14 \mathrm{~nm}$. Since this radiation is used not only in excimer UV lamps but also in mercury-free fluorescent lamps and plasma displays we mention some of the more important aspects. In low pressure xenon discharges an extremely narrow resonance line at $147 \mathrm{~nm}$ is emitted. Its intensity increases with pressure and peaks around $100 \mathrm{~Pa}$ [77]. The decay above this pressure is due to self absorption of the emitted radiation and quenching of the excited atoms. If the pressure is further increased a wider spectral emission appears in the same spectral range with a shoulder 
towards longer wavelengths. This emission is referred to as the first excimer continuum of xenon. At pressures above about $10 \mathrm{kPa}$ the second excimer continuum around $172 \mathrm{~nm}$ appears and completely dominates above $50 \mathrm{kPa}$. It results from a transition of the lower vibrational levels of the excimer states ${ }^{1} \Sigma_{u}^{+},{ }^{3} \Sigma_{u}^{+}$to the repulsive ground state. From electron beam experiments and numerical simulations it is known that this emission can reach an efficiency of $40-50 \%$ [78-80] and that extremely high power densities $>1 \mathrm{MW} \mathrm{cm}$-3 can be achieved. Our own calculations indicate that similar efficiencies can be reached in DBDs [11]. Fig. 10 shows computations of the efficiency for different assumed electron densities at $100 \mathrm{kPa}$ and the pressure dependence of the different emission features neglecting radiation trapping of the resonance line. Recorded emission spectra, also presented in Fig. 10, show that at $68 \mathrm{kPa}$ only the second excimer continuum is emitted. At this pressure excimer formation is faster than any decay or quenching processes of the excited precursor species $\mathrm{Xe}^{*}\left({ }^{3} \mathrm{P}_{1,2}\right)$.
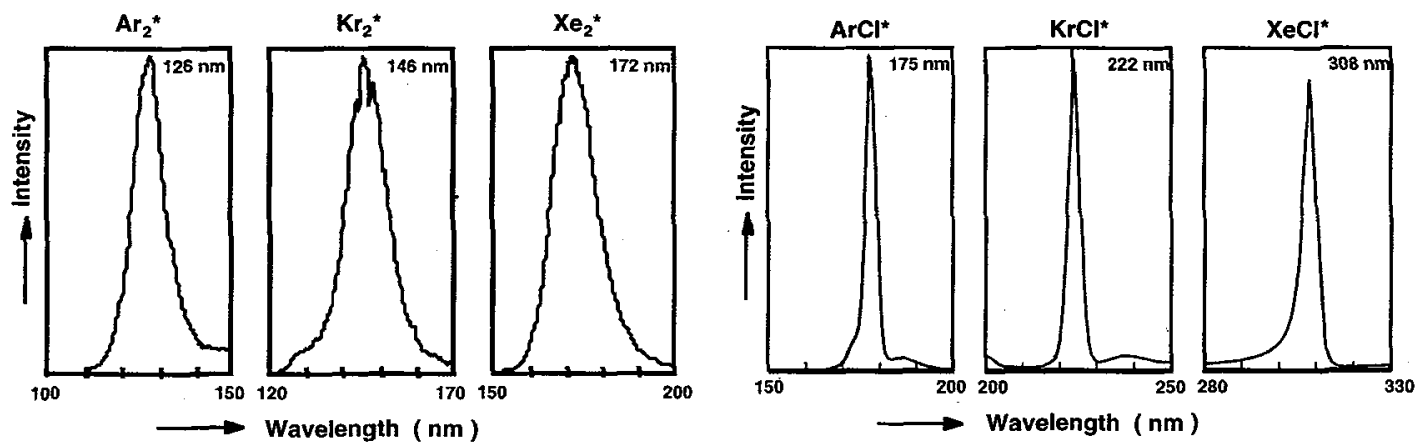

Fig. 9: Emission spectra of different excimer lamps [73]

Quite a few additional DBD lamps with excimer emission in the VUV, UV or visible spectral range have been investigated [73-76,81]. In addition to the simple geometrical configurations of Fig. 8 also large-area and windowless excimer lamps have been proposed [73,82-84]. The main advantage of excimer lamps is that they provide high-intensity narrow-band radiation that, due to the absence of a stable excimer ground state, can leave the plasma without reabsorption. If properly cooled this high radiation output can be obtained at low lamp temperature. The excimer formation process is completed within some ns and the excimer radiation decays in about $100 \mathrm{~ns}$. As a consequence, excimer lamps can be switched on and off at extremely fast rates. A lamp driven at a fundamental frequency of $100 \mathrm{kHz}$, for example, emits bursts of short light pulses at a repetition rate of $200 \mathrm{kHz}$. Excimer lamps need no warmup time and can be operated even at cryogenic temperatures. Another important advantage is the flexibility of the sandwich like electrode configuration which can be formed to any desired shape. Excimer lamps found a number of interesting novel applications and, within a short period of time, became commercially available in Germany, in Japan and in the United States.
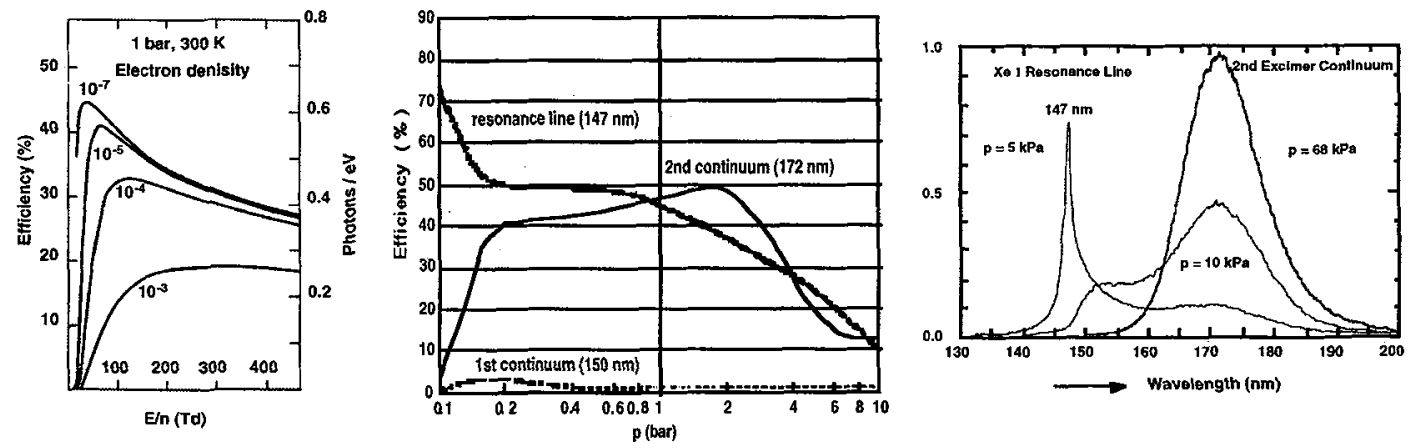

Fig. 10: Computation of the UV efficiency at $172 \mathrm{~nm}$ and pressure dependence and measured emission spectrum of a xenon dielectric-barrier discharge (in the computations radiation trapping of resonance radiation is neglected) $[11,12,73]$ 


\subsection{Novel Applications of Excimer Lamps}

Soon after the first prototypes of excimer lamps became available it was realised that these novel UV and VUV sources will find a number of interesting industrial applications $[57,71,73,85]$. As opposed to most other lamps excimer UV sources provide selective intense UV radiation at specific wavelengths. This narrow-band UV radiation can initiate chemical reactions, break molecular bonds or modify surface properties. At shorter wavelengths the absorption coefficient of most substances increases. So, in many cases the UV radiation is absorbed in a very thin surface layer. Like other UV sources excimer lamps can be used to induce photo-polymerisation of special paints, varnishes, adhesives, a process called UV curing. The special capabilities of excimer lamps in providing large-area intense narrow-band UV irradiation at low temperature, without producing ozone at the same time, immediately led to first applications on printing machines for high speed drying of UV printing inks. For this application the $\mathrm{XeCl}^{*}$ lamp is used. Novel applications, especially for the shorter UV and VUV wavelengths, were found in materials processing and pollution control.

\subsubsection{Material Deposition with Excimer Lamps}

Excimer lamps emitting UV or VUV radiation have proved very useful tools for the photo cleavage of precursor substances that lead to the deposition of metallic, dielectric or semiconducting layers. Substantial work has been reported on the mechanism of area-selective deposition of copper structures following UV induced palladium nucleation from palladium(II) acetate precursor films[57,71,85-92]. By irradiating a spin coated or dip coated Pd acetate film with UV radiation from an excimer lamp palladium nucleation of the surface is obtained. This well adhering Pd interface of a few nm thickness serves as the starting point for a subsequent electroless plating process. This low temperature metallisation has potential applications in microcircuits, multichip interconnects and prototype fabrication. Within a few years this process was brought to technical maturity in the Brite/EuRam PACE project focusing on Photo Assisted Catalysis of Electroless Plating.

Photo-induced deposition of insulating films has also become an important application of excimer lamps. Low temperature deposition of good quality silicon dioxide and silicon nitride films were obtained by irradiating silane/nitrous oxide/ammonia mixtures [93-96]. By carefully adjusting the gas mixture any desired $\mathrm{SiO}_{\mathrm{x}} \mathrm{N}_{\mathrm{y}}$ composition could be obtained. The dielectric constant of the deposited film could be varied between that of pure $\mathrm{SiO}_{2}$ and that of pure $\mathrm{Si}_{3} \mathrm{~N}_{4}$. The oxides of silicon, lanthanum and aluminium have also be obtained by irradiating sol-gel metal organic precursor films [87,96,97]. Also tantalum oxide films were obtained by irradiating tantalum ethoxide sol-gel films with a xenon excimer lamp. Due to its high dielectric constant of about 25 it is a promising candidate as a capacitor dielectric in high density dynamic assess memories (DRAMS) and in ultra-large scale integrated (ULSI) devices [98]. Recently also the photoinduced deposition of polyimide films was demonstrated [99]. Polyimide is of great interest as a low dielectric constant material $(\varepsilon=3.1)$ for faster semiconductor devices in which it could replace the $\mathrm{SiO}_{2}(\varepsilon=4.2)$ as an interlayer dielectric. With the aid of UV radiation from a xenon excimer lamp thin polyimide films were obtained from polamic acid precursor coatings spun onto a silicon substrate. With UV irradiation complete imidisation could be achieved at low temperature. Sample metal-insulator semiconductor diodes incorporating these new UV cured polyimides showed much lower leakage current than diodes with thermally cured polyimide.

Also the UV induced deposition of amorphous semiconductor layers from gaseous precursors was demonstrated. Again the $172 \mathrm{~nm}$ radiation of the xenon excimer lamp was used. Good quality a-Si:H films were obtained by irradiating $\mathrm{Si}_{2} \mathrm{H}_{6}$ [101-103], semiconducting silicon carbide films by adding $\mathrm{C}_{4} \mathrm{H}_{10}$ and $\mathrm{a}-\mathrm{Ge}: \mathrm{H}$ films from $\mathrm{GeH}_{4}$ as a precursor.

\subsubsection{Surface Modification with Excimer Lamps}

As soon as excimer lamps became available it was realised that these novel VUV and UV sources offered enormous potential for materials processing [84,85,87]. Among the first applications were surface modification and polymer etching [84,87-89]. Irradiation of PTFE (polytetrafluroethylene, Teflon) with VUV radiation from xenon or krypton excimer lamps under ammonia atmosphere results in hydrophilic surfaces. The changes are attributed to the incorporation of nitrogen, hydrogen and oxygen atoms into the surface [107]. Also dry photochemical selective etching of InGaAs on InAlAs was demonstrated with a xenon excimer lamp [108]. In this case a $\mathrm{HBr}$ gas atmosphere at a pressure of $12 \mathrm{kPa}$ was used. An excellent selectivity of over 100 was achieved for this material system. Important applications are foreseen for the fabrication of electrical as well as optical devices using InGaAs/InAlAs heterojunctions, e.g. high electron mobility transistors (HEMTs) for microwave applications as well as monolithic integration of photodiodes. Very recently also the direct oxidation of silicon at fairly low temperatures was demonstrated by Boyd and Zhang with a xenon excimer lamp [109]. At $250^{\circ} \mathrm{C}$ direct photooxidiation 
of silicon was achieved at a rate of $0.1 \mathrm{~nm} / \mathrm{min}$ which was about 100 times faster than thermal oxidation at $612{ }^{\circ} \mathrm{C}$. The grown films had excellent electrical properties with respect to fixed oxide charge density, leakage current and breakdown field, comparable to those of thermaily grown oxide on $\mathrm{Si}$. This new photo assisted oxidation process can become a fast fabrication process for integrated circuits with only moderate increase of the thermal budget of the treated device.

\subsubsection{Pollution Control with Excimer UV and VUV Radiation}

The availability of new intense VUV and UV sources prompted a number of investigations in the photodegradation of pollutants in gaseous [110-113] and aqueous media [110,114-118]. Many of the common pollutants (TCE; PCE, DCE, $\mathrm{CCl}_{4}, \mathrm{CH}_{3} \mathrm{Cl}$ ) absorb strongly in the ultraviolet spectral range close to $200 \mathrm{~nm}$. Their molecular absorption cross sections can be well in excess of $10^{-17} \mathrm{~cm}^{2}$. This value is more than million times larger than that of water or air in this spectral range. Consequently selective photodegradation of micropullutants at low concentration becomes possible [110]. The VUV radiation of the xenon excimer lamp is energetic enough to induce photocleavage of water and oxygen. Both substances absorb strongly at $172 \mathrm{~nm}$. In both cases highly reactive radicals $\mathrm{O}\left({ }^{1} \mathrm{D}\right), \mathrm{O}\left({ }^{3} \mathrm{P}\right), \mathrm{OH}$ are generated that can be utilised for pollution control. In general, the VUV process is very simple and has the particular advantage that no chemicals need to be added. The process represents a real challenge to other photochemical water treatment processes [119]. Treatment of contaminated surface water, ground water as well as waste water containing biocidal or nonbiodegradable components is under investigation. Oxidative degradation following VUV photolysis of water, due to its simplicity, has fast become an attractive alternative to other advanced oxidation (AOP) processes [119-121].

\section{FLUORESCENT LAMPS AND PLASMA DISPLAYS}

Efficient generation of VUV excimer radiation can also be utilised for fluorescent lamps. With the aid of phosphors visible radiation can be generated for a number of different applications. It is possible to produce mercury free fluorescent lamps with obvious advantages for the environment. The efficiencies obtained so far do not reach those of lamps based on the $254 \mathrm{~nm}$ resonance line of mercury. The advantage of fluorescent lamps based on $\mathrm{Xe}_{2}{ }^{*}$ excimer radiation could be much higher luminescence intensities that can be reached due to the absence of radiation trapping in the lamp. A second advantage over mercury-based lamps is that operating conditions are practically independent of ambient temperature and that the excimer formation process is extremely fast. There are a number of applications where instant availability and short pulse operation is of advantage, for example in copying machines. A third advantage is the flexibility of dielectric-barrier discharges with respect to conceivable geometries. Some interesting work has been performed with respect to ultra flat fluorescent lamps that have been developed for LCD backlightirig $[122,123]$. This way large-area panels of uniform luminance can be realised. Typical gap spacings are $0.5-2 \mathrm{~mm}$ and the filling pressure is about $10-40 \mathrm{kPa}$. Pure xenon or also xenon/neon mixtures can be used. The DBD is enclosed between two soda-lime glass plates. The back electrode is a silver layer covered with a printed dielectric and a phosphor layer. The front glass plate is covered by phosphor on the inside and by a transparent ITO (indium/tin oxide) electrode on the front side. Such panels can be operated by $30 \mathrm{kHz}$ sine wave or square wave excitation at about $1000 \mathrm{~V}_{\text {rms }}$. Phosphor layers containing e. g. $\mathrm{Y}_{2} \mathrm{O}_{3}: \mathrm{Eu}$ or $(\mathrm{Y}, \mathrm{Gd}) \mathrm{BO}_{3}: \mathrm{Eu}$ for red light, $\mathrm{LaPO}_{4}: \mathrm{Ce}, \mathrm{Tb}, \mathrm{BaAl}_{12} \mathrm{O}_{19}: \mathrm{Mn}$ or $\mathrm{Zn}_{2} \mathrm{SiO}_{4}: \mathrm{MN}$ for green light and $\mathrm{BaMgAl}_{14} \mathrm{O}_{23}:$ Eu or $\mathrm{BaMgAl}_{16} \mathrm{O}_{27}:$ Eu for blue light have been proposed $[123,129]$. Blends of different phosphors yield white light. Luminous efficiencies of about $30 \mathrm{~lm} / \mathrm{W}$ at a relatively high luminance of $3500 \mathrm{~cd} / \mathrm{m}^{2}$ and at power densities of $40 \mathrm{~mW} / \mathrm{cm}^{2}$ were reported [123].
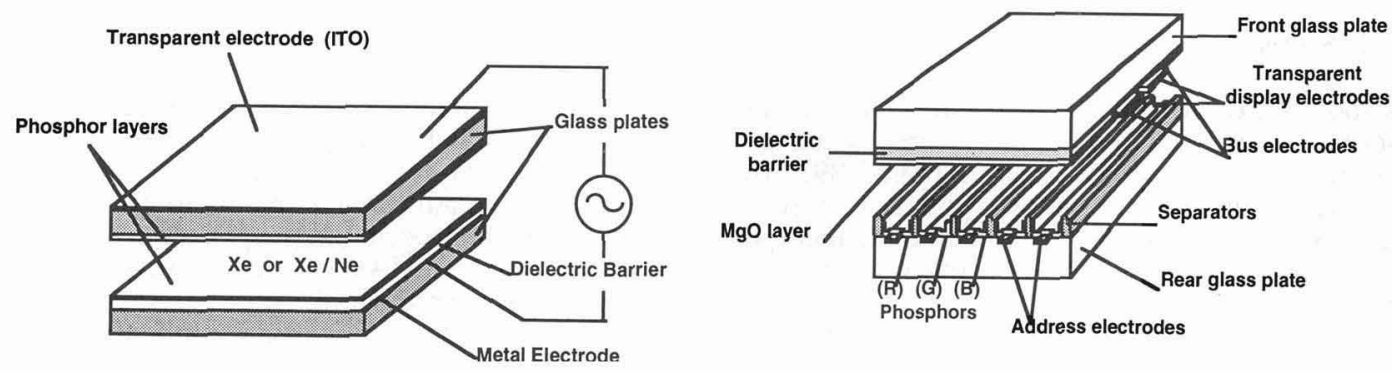

Figure 11: Flat fluorescent lamp and ac plasma display cell based on excimer radiation generated in a dielectric-barrier discharge. 
One of the most fascinating recent applications of DBDs results from its enormous potential for miniaturisation. The new generation of large-area ac plasma displays just entering the marked are based on dielectric-barrier discharges. Each colour pixel is a miniature excimer fluorescent lamp. It now appears that large-area displays for flat HDTV displays will use plasma display panels (PDPs) rather than TFT (thin film transistor) liquid crystal technology. The manufacturing of plasma displays profits from low material costs, inexpensive high throughput thick film processes and moderate cleanroom requirements. Prototype PDPs of excellent resolution and brilliance have been presented and mass production has started in Japan at several manufacturing sites. These displays with currently 40 inch diagonal are expected to eventually replace cathode ray tubes (CRTs) in television and large-area monitor applications. The plasma display itself can be made as thin as $6 \mathrm{~mm}$ although the whole package still measures $5-10$ $\mathrm{cm}$ in thickness. The viewing angle is $140^{\circ}$, comparable to that of CRTs and superior to that of LCDs. The power consumption is comparable to that of conventional TV sets, about $200-300 \mathrm{~W}$. The weight of a PDP is about $10-30 \mathrm{~kg}$ compared to more than $150 \mathrm{~kg}$ for a CRT display of comparable size. In addition to the obvious use as a flat TV set there are a number of important other uses for bright largearea displays in industrial, medical and military applications [124-127].

The discharge gap width in PDPs is reduced to $80-100 \mu \mathrm{m}$ and the width of each cell is about 200 $\mu \mathrm{m}$. Adjacent cells are separated by ribs of typically $50 \mu \mathrm{m}$ thickness and $100 \mu \mathrm{m}$ height to reduce cross talk between neighbour cells (Fig. 11). These cells can be sandblasted or etched into a flat glass plate or formed by thick film printing processes, relatively inexpensive manufacturing technologies. The filling gas is a helium/xenon or neon/xenon mixture at filling pressures between 10 and $100 \mathrm{kPa}$. Two sets of perpendicalar rows of thin electrode strips allow to address each individual cell . In ac PDPs the electrodes are coated by dielectrics and thin protective layers of magnesium oxide. MgO's low sputtering rate assures long life times and its high coefficient of secondary electron emission is taken advantage of for lowering the operating voltage. PDPs can be operated by $200 \mathrm{~V}$ integrated driver circuits.

UV radiation of excited xenon atoms and excimers activates appropriate phosphor layers deposited on the inner wall of the gas cells. Colour triples RGB (red green blue) or quadruplets RGBG form one image point of the display. The pitch of these pixels is about $0.3-0.6 \mathrm{~mm}$. While neon and helium are used as buffer gases xenon is used for the generation UV radiation. Mainly the Xe resonance line at 147 $\mathrm{nm}\left(\mathrm{Xe}^{* 3} \mathrm{P}_{1}\right)$ and the first and second excimer continua at $150 \mathrm{~nm}$ and $172 \mathrm{~nm}$ originating from $\mathrm{Xe}_{2}{ }^{*}$ excimer molecules $\left(\mathrm{O}_{\mathrm{u}}^{+},{ }^{3} \Sigma_{\mathrm{u}}^{+}\right.$and $\left.{ }^{1} \Sigma_{u}^{+}\right)$are detected in the emission spectrum. While the resonance radiation is subjected to strong self absorption in the gas, a process referred to as radiation trapping or radiation imprisonment, the excimer radiation can escape from the plasma with practically no absorption. Higher pressures favour the second excimer continuum at $172 \mathrm{~nm}$. Above about $10 \mathrm{kPa}$ the three body reaction of excited xenon atoms leading to the formation of xenon excimer complexes becomes faster than de-excitation of $\mathrm{Xe}^{*}[11,12]$. The main reason for using a buffer gas is to lower the operating voltage to levels that can be handled by transistors. $\mathrm{MgO}$ has an extremely large secondary electron emission coefficient for impinging $\mathrm{Ne}^{+}$ions resulting in a cathode fall voltage drop of only $95 \mathrm{~V}$. Mole fractions up to $95 \%$ neon can be used. Detailed 1D [128-130] or 2D [125,131,132] computer models of discharge development and radiation characteristics in xenon/neon mixtures in PDP cells have been presented. A review of the physics and modelling of plasma display panels can be found in the paper by J.-P. Boeuf in this volume.

Typical sustaining frequencies for ac displays are of the order $50-100 \mathrm{kHz}$ with current pulse duration of about $20 \mathrm{~ns}$, depending on the rise time of the square wave driving voltage, gas mixture and geometry. The intensity of a cell is adjusted by using duty cycle modulation. 256 grey levels and 16 million colours can be obtained, resulting in extremely bright and colourful pictures. So far the luminance and luminous efficiency of PDPs reach $400 \mathrm{~cd} / \mathrm{m}^{2}$ and $1 \cdot \mathrm{lm} / \mathrm{W}$, respectively. This corresponds to an energy conversion of only about $0.3 \%$. For a good display these values should be raised to $700 \mathrm{~cd} / \mathrm{m}^{2}$ and $5 \mathrm{~lm} / \mathrm{W}$ to match the performance of CRTs [127]. The basic structure and the exposed materials are extremely durable so that panel lifetimes should eventually reach those of monochrome PDPs, reported to be close to 100000 hours.

The technological breakthrough that recently led to massive investment in large-volume production facilities for flat plasma display panels is based on three developments: Overcoming the limitations of self-absorption by using $\mathrm{Xe}_{2}$ excimer radiation, developing phosphors that are immune to VUV radiation damage and making prudent use of $\mathrm{MgO}$ protective coatings in combination with the buffer gas neon to keep the discharge voltage low at pressures high enough to ensure excimer formation. Expectations are that this most recent application of dielectric-barrier discharges, within a few years, will become the most important one as far as sales volumes are concerned.

\section{SD $\mathrm{CO}_{2}$ LASERS}

Dielectric-barrier discharges are extensively used today to pump high power $\mathrm{CO}_{2}$ lasers. Ishchenko, 1978 [133] and Christensen, 1979 [134] were probably the first to use pulsed DBDs to obtain $\mathrm{CO}_{2}$ laser pulses. 
Only two years later the concept of a high power quasi-DC $\mathrm{CO}_{2}$ laser excited by DBDs was presented by Yagi and Tabata [135], a team that could build on its experience with ozone generation. This $\mathrm{SD}_{2}$ laser (SD for silent discharge) soon became the most successful commercial laser for material processing on the Japanese market. The water cooled plane metal electrodes are covered by glass or alumina dielectrics and are separated by $20-50 \mathrm{~mm}$. A high-velocity cross flow passes the discharge gap at 50 $80 \mathrm{~m} / \mathrm{s}$ for heat removal and discharge stabilisation. Typical gas mixtures are $\mathrm{CO}_{2} / \mathrm{N}_{2} / \mathrm{He}(1 / 8 / 4)$ at a total pressure of $6.5-20 \mathrm{kPa}$ [136 - 138]. The discharge looks fairly homogeneous and has been referred to as an ion trapping discharge. There is not enough time for the ions to decay or be removed between succeeding half waves. As a consequence, the discharge behaves very much like a resistive load. The current/voltage diagram is almost a straight line and the voltage/charge Lissajous figure looks like an ellipse. The discharge is maintained by a high voltage sine wave supplied by transistorised power supplies operating at between 100 and $500 \mathrm{kHz}$, typically at $170 \mathrm{kHz}$. Nearly diffraction limited infrared radiation is obtained at a power level of $5 \mathrm{~kW}$ and an efficiency surpassing $10 \%$. High speed welding and cutting of metal plates and other materials is the main application of this $\mathrm{SD} \mathrm{CO}$ laser.

\section{POLLUTION CONTROL WITH DBDs}

Applications of DBDs to the destruction of poisonous compounds and to pollution control in general has received growing attention. After initial work on military toxic wastes by Clothiaux et al. in 1984 [139] and Fraser and Sheinson in 1986 [140] an increasing number of investigations were devoted to the decomposition of nitrogen oxides and sulphur oxides, and of volatile organic compounds (VOCs) such as hydrocarbons, chlorocarbons and chlorofluorocarbons (CFCs) in silent discharges. Contamination of exhaust air with gaseous hydrocarbons or organic solvent vapours occurs in many industrial processes, e. g. in chemical processing, in print and paint shops, in semiconductor processing as well as in soil remediation and water treatment. Much of the more recent work was discussed at the 1992 NATO Advanced Research Workshop on Non-Thermal Plasma Techniques for Pollution Control [141]. An upto-date review by $\mathrm{L}$. A. Rosocha exclusively devoted to the use of silent discharges for processing hazardous chemicals was published earlier this year [142].

Many hazardous organic chemical are readily attacked by free radicals, electrons or UV photons. DBDs are used to provide reactive species such as $\mathrm{N}_{2}{ }^{*}\left(\mathrm{~A}^{3} \Sigma_{\mathrm{u}}{ }^{+}\right), \mathrm{N}_{2}{ }^{*}\left(\mathrm{~B}^{3} \Pi_{\mathrm{g}}\right), \mathrm{O}_{2}{ }^{*}\left(\mathrm{a}^{1} \Delta_{\mathrm{q}}\right), \mathrm{O}\left({ }^{1} \mathrm{D}\right), \mathrm{O}\left({ }^{3} \mathrm{P}\right), \mathrm{H}, \mathrm{OH}$, and $\mathrm{N}$. These species initially formed by electron collisions in the microdischarge filaments subsequently provide a number of reaction paths to generate additional $\mathrm{O}, \mathrm{OH}$ or $\mathrm{HO}_{2}$ radicals:

$$
\begin{array}{ll}
\mathrm{N}_{2}{ }^{*}+\mathrm{H}_{2} \mathrm{O} & \Rightarrow \mathrm{OH}+\mathrm{H}+\mathrm{N}_{2} \\
\mathrm{~N}_{2}{ }^{*}\left(\mathrm{~B}^{3} \Pi_{\mathrm{g}}\right)+\mathrm{O}_{2} & \Rightarrow \mathrm{O}\left({ }^{1} \mathrm{D}\right)+\mathrm{O}\left({ }^{3} \mathrm{P}\right)+\mathrm{N}_{2} \\
\mathrm{~N}_{2}{ }^{*}\left(\mathrm{~A}^{3} \Sigma_{\mathrm{u}}{ }^{+}\right)+\mathrm{O}_{2} & \Rightarrow \mathrm{O}\left({ }^{3} \mathrm{P}\right)+\mathrm{O}\left({ }^{3} \mathrm{P}\right)+\mathrm{N}_{2} \\
\mathrm{O}\left({ }^{1} \mathrm{D}\right)+\mathrm{H}_{2} \mathrm{O} & \Rightarrow \mathrm{OH}+\mathrm{OH}
\end{array}
$$

$$
\begin{aligned}
& \mathrm{O}+\mathrm{HO}_{2} \Rightarrow \mathrm{OH}+\mathrm{O}_{2} \\
& \mathrm{~N}+\mathrm{O}_{2} \Rightarrow \mathrm{NO}+\mathrm{O} \\
& \mathrm{H}+\mathrm{HO}_{2} \Rightarrow \mathrm{OH}+\mathrm{OH} \\
& \mathrm{O}_{3}+\mathrm{OH} \Rightarrow \mathrm{HO}_{2}+\mathrm{O}_{2}
\end{aligned}
$$

These radicals can subsequently react with hazardous compounds to form non-hazardous or less hazardous substances such as $\mathrm{O}_{2}, \mathrm{O}_{3}, \mathrm{CO}, \mathrm{CO}_{2}, \mathrm{H}_{2} \mathrm{O}$, simple acids or, upon addition of ammonia for example, solid salt particles. In humid gas streams like combustion exhaust gases the hydroxyl radical $(\mathrm{OH})$ plays an important role. This radical is also responsible for the cleaning of the troposphere [143].

In the case of chlorinated compounds typical destruction products are also chlorine and hydrochloric acid. In this case catalytic reaction schemes involving $\mathrm{ClO}$ and $\mathrm{ClO}_{2}$ can become important. Care must be take to avoid formation of even more toxic compounds. A famous example is the formation of extremely toxic phosgen $\left(\mathrm{COCl}_{2}\right)$, a combat gas of the first world war, when decomposing chlorocarbons in dry air streams. So safety precautions and good diagnostics are essential for such investigations. Quite a few successful laboratory and pilot investigations have been reported in the literature. The removal of $\mathrm{NOx}$ and $\mathrm{SO}_{2}$ from air and flue gas streams or exhausts was investigated by several groups [144-151]. Also the destruction of formaldehyd (HCHO) [151,152], carbon tetrachloride $\left(\mathrm{CCl}_{4}\right)[142,157]$, trichloroethylene $\left(\mathrm{TCE}, \mathrm{ClHC}=\mathrm{CCl}_{2}\right)[142,154,155]$, perchloroethylene $\left(\mathrm{PCE}, \mathrm{C}_{2} \mathrm{Cl}_{4}\right)$ [51], methylene chloride $\left(\mathrm{CH}_{2} \mathrm{Cl}_{2}\right)$, benzene $\left(\mathrm{C}_{6} \mathrm{H}_{6}\right)$ [153], toluene (methylbenzene, $\left.\mathrm{C}_{6} \mathrm{H}_{5} \mathrm{CH}_{3}\right)$ and xylene (dimethylbenzene, $\left.\mathrm{C}_{6} \mathrm{H}_{4}\left(\mathrm{CH}_{3}\right)_{2}\right)$ [156], $\mathrm{H}_{2} \mathrm{~S}$ and $\mathrm{NH}_{3}[158,159]$ and methanol $\left(\mathrm{CH}_{3} \mathrm{OH}\right)$ [155] was given special attention.

As compared to incineration and thermal plasma treatment the advantage of using a non-equilibrium discharge is that most of the discharge energy can be utilised to accelerate electrons and generate free radicals. In dielectric-barrier discharges the conditions in the microdischarges can be optimised to produce sufficient free radicals for the intended destruction reaction and avoid concentrations where radical-radical reassociation or annihilation reactions become important. This can be achieved at gas temperatures close to room temperature and atmospheric pressure, a condition which is of utmost importance for flue gas or off gas treatment. DBDs are considered especially if pollutant concentrations 
are low, say in the 10 to $1000 \mathrm{ppm}$ range. The main reason is that for dilute pollution concentrations raising the temperature of the complete carrier gas stream to incineration temperatures or only to temperatures where catalytic destruction can be initiated $\left(200-500^{\circ} \mathrm{C}\right)$ becomes uneconomic. DBDs may also have advantages over conventional methods when different pollutants have to be treated simultaneously. Also additional effects caused by UV radiation $[21,149,157,160]$ or inserted dielectric pellets $[153,161,162]$ are under investigation.

When compared to pulsed positive corona and electron beam treatment DBDs have the advantage of much easier up-scaling and simpler power supply units. Electron beams have to be accelerated under high vacuum conditions and then transferred through special windows to the reaction chamber, which again has to be sized with respect to the penetration depth of the electrons. Pulsed corona discharges according to many investigations reach removal efficiencies similar to those of DBDs but require special pulsed power supplies to initiate and terminate the pulsed streamer corona. The microdischarge mechanism active in DBDs, on the other hand, is self-terminating and works over a large range of supply frequencies with different voltage or current shapes. As a consequence, non-thermal plasma remediation of air pollutants using dielectric-barrier discharges has become a promising fast growing technology.

\section{SURFACE MODIFICATION WITH DBDS}

Many plastic surfaces are not easily wetted so that it may be difficult or even impossible to glue, paint or print on them. In many cases it is possible to activate such surfaces by a plasma treatment, a process often referred to as "corona treatment" [163]. In most applications in reality a dielectric-barrier discharge is used. Typically, the work piece or a coating on the transport rolls or high voltage electrodes serves as a dielectric barrier. To treat large foils on one or both sides they are passed at high speed under a silent discharge maintained by an alternating high voltage applied between a knife edge electrode and a drum covered by a dielectric (Fig. 12). In many applications electrode assemblies of several parallel knife edges are used. Foils up to $10 \mathrm{~m}$ width are treated at a speed of about $10 \mathrm{~m} / \mathrm{s}$. This requires a discharge power of about $100 \mathrm{~kW}$. Useful operating frequencies are in the range of $10-50 \mathrm{kHz}$.

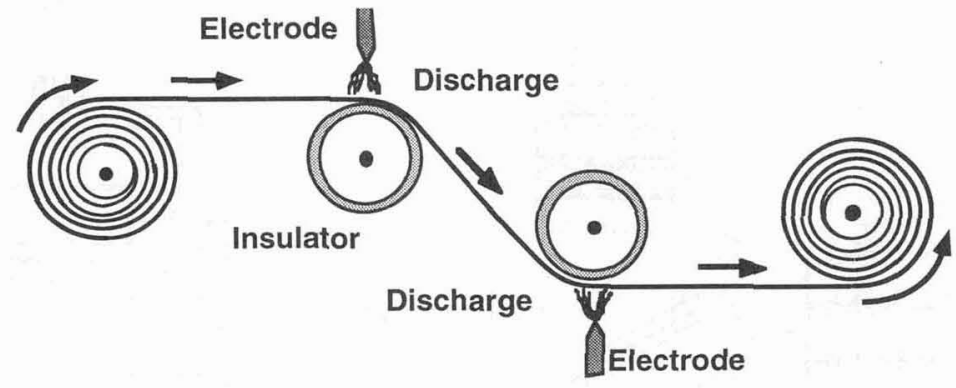

Fig. 12: Schematic diagram of high speed DBD treatment of plastic foils

Also the deposition of thin films in dielectric-barrier discharges has been investigated. In 1979 Donohoe and Wydeven [164] described a plasma polymerisation reactor operating at atmospheric pressure. One group around S. Okazaki and M. Kogoma [165-168] felt that the discrete microdischarges are not ideal for this purpose and tried to get a homogeneous discharge which they called APG (atmospheric pressure glow) discharge. The spatial homogeneity of DBDs can be influenced by using two dielectric barriers and specially shaped metal electrodes, by the operating frequency, by using large fractions of helium or neon or certain other additives like acetone or methane in argon. This work on homogeneous DBDs was further investigated by Massines and co-workers [169,170]. An alternative approach was presented in recent years by J. Salge and co-workers [171-174]. They showed that by using pulsed dielectric-barrier discharges the properties of microdischarges can be influenced in such a manner that superior surface modification and coatings of excellent quality can be obtained. Special power supplies were developed to generate repetitive pulse trains resulting in improved statistical distribution of the microdischarges across the surface, a prerequisite for more uniform treatment. Working in acetylene pin-hole-free polymeric films with properties resembling those of polyacetylene were obtained. Also thin deposits of silicon oxide were obtained at atmospheric pressure in a atmosphere of propargyl alcohol vapour and silane. In both cases the surface tension of polypropylene foils could be doubled from $30 \mathrm{mN} / \mathrm{m}$ to more than $70 \mathrm{mN} / \mathrm{m}$ [174].

The possibility to treat or coat surfaces at low temperature and close to atmospheric pressure is an important advantage for large-scale industrial applications. It is to be expected that coating techniques 
using vapour or gas phase deposition in DBDs and also the annealing and oxidation of sol-gel films subjected to DBDs will be further developed.

\section{GREENHOUSE GAS RECYCLING WITH DBDs}

Recent research activities in the field of dielectric-barrier discharges address the problem of global warming and threatening climate changes. Global warming due to anthropogenic emissions of greenhouse gases has long been discussed among scientists as a possible cause for observed climate changes. The $\mathrm{CO}_{2}$ concentration in the atmosphere that had been constant at approximately $280 \mathrm{ppm}$ for at least 1000 years started to rise around 1750 with the advent of industrialisation and increased use of fossil fuels. Within only 200 years the $\mathrm{CO}_{2}$ concentration in the atmosphere rose to $360 \mathrm{ppm}$ and is rising at an increasing rate. As a result of a full evaluation of the available scientific evidence the United Nation's Intergovernmental Panel on Climate Change (IPCC) recently came to the conclusion that current warming "is unlikely to be entirely natural in origin" and that "the balance of evidence suggests a discernible human influence on global climate." The IPCC recommends a $50 \%$ reduction of global $\mathrm{CO}_{2}$ emissions within the next fifty years. This goes far beyond the commitments made by many industrial nations at the 1992 Rio World Environmental Summit. The recommendation then was to stabilise $\mathrm{CO}_{2}$ emissions at the level of that of 1990 by the year 2000 . As far as emitted quantities are concerned the major greenhouse gases are carbon dioxide and methane. Close to $60 \%$ of the man-made greenhouse effect can be attributed to $\mathrm{CO}_{2}$ emissions which amount to $30 \mathrm{Gt}$ per year. Of this amount about $22 \mathrm{Gt}$ result from the combustion of fossil fuels. World wide about two thirds of the power plants run on fossil fuels and their flue gases contain typically between 4 and $14 \% \mathrm{CO}_{2}$. The availability of coal and the need of additional electric power especially in China and India will result in many new coal-fired power plants in the next decades. Concern about possibly irreversible climate changes and impending international legislation restricting or penalising these emissions has prompted extensive research activities aimed at $\mathrm{CO}_{2}$ disposal and $\mathrm{CO}_{2}$ utilisation. One proposal is to recycle $\mathrm{CO}_{2}$ as an energy carrier, perhaps combined with hydrogen in the form of a liquid fuel, or as a feed stock in the chemical industry [175].

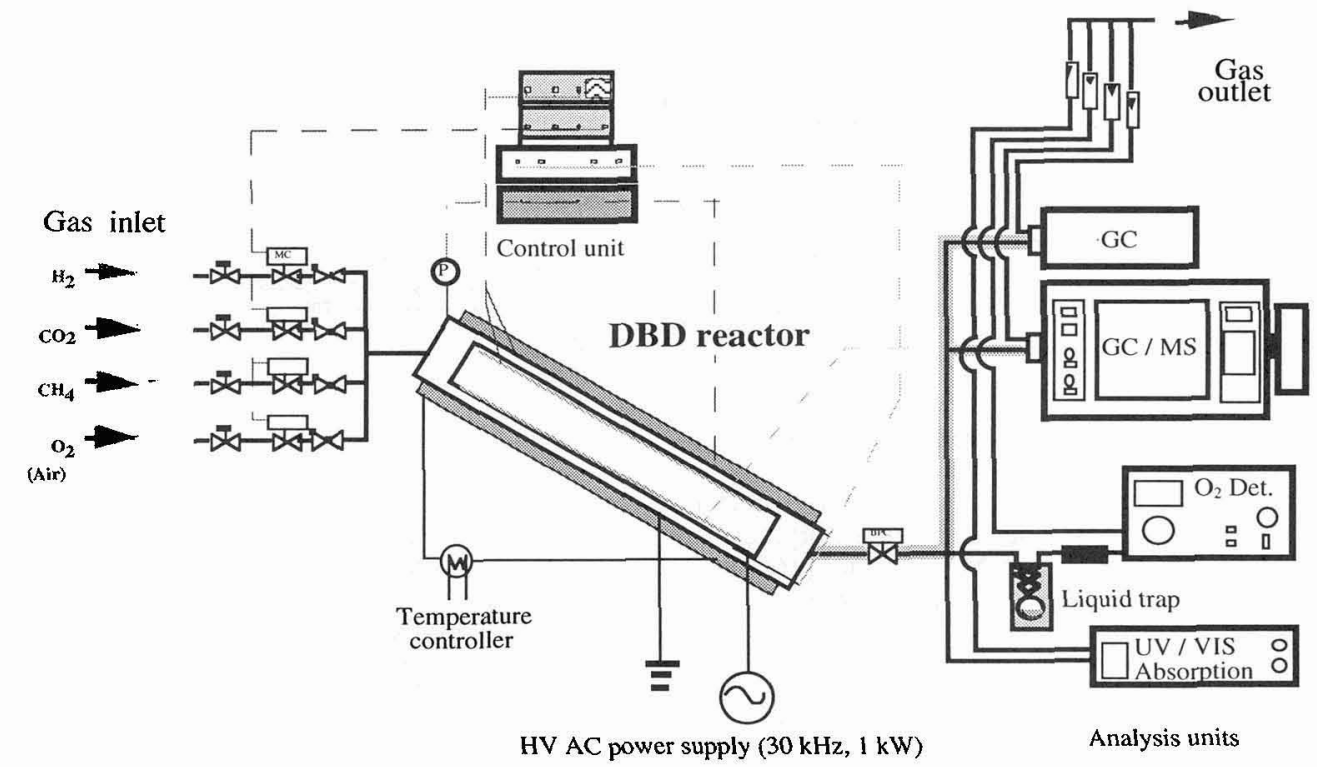

Fig. 13: Dielectric-barrier discharge reactor for greenhouse gas investigations

To investigate the decomposition of greenhouse gases and possible routes to their utilisation we designed a DBD reactor that can be operated over a wide temperature and pressure range. We studied the decomposition of the greenhouse gases $\mathrm{CO}_{2}$ and $\mathrm{CH}_{4}$ under different operating conditions. It could be demonstrated that both gases can be decomposed in the discharge and that new products are formed. The DBD reactor can be operated at pressures up to $1 \mathrm{MPa}$ and regulated wall temperatures up to $400^{\circ} \mathrm{C}$. A high voltage power supply operating close to $30 \mathrm{kHz}$ can adjust the discharge power between $100 \mathrm{~W}$ and $1 \mathrm{~kW}$. Under different operating conditions the decomposition of the main greenhouse gases $\mathrm{CO}_{2}$ and $\mathrm{CH}_{4}$ 
was studied [176]. Formation of $\mathrm{CO}, \mathrm{O}_{2}$ and $\mathrm{O}_{3}$ is observed when $\mathrm{CO}_{2}$ is treated. $\mathrm{H}_{2}, \mathrm{C}_{2} \mathrm{H}_{6}$ and higher alkanes are detected when pure $\mathrm{CH}_{4}$ is used. In methane/oxygen mixtures methanol is formed together with $\mathrm{CO}$ and $\mathrm{H}_{2} \mathrm{O}$ [176-178]. We could show that methanol can also be synthesised from $\mathrm{CH}_{4} /$ air mixtures. $\mathrm{MeOH}$ is an attractive synthetic fuel which has twice the energy density of liquid hydrogen. Being a liquid at ambient conditions it can readily be stored and transported. It has a large potential for being used as a fuel in motor vehicles and stationary combustion sources or as a chemical storage medium for electrical energy. In our labs also methanol synthesis from $\mathrm{CO}_{2}$ and hydrogen, or possibly a hydrogen donor, is investigated. The $\mathrm{CO}_{2}$ could be recovered from the exhaust of a power plant operating on fossil fuels. In addition to DBDs and catalytic reactors also the suspension of fine grain catalysts in a dielectric-barrier discharge is studied [179]. It could be demonstrated that the presence of the discharge plasma can substantially reduce the activation energy of the catalyst and, on the other hand, the presence of the catalyst can substantially increase the selectivity of the dielectric-barrier discharge with respect to methanol formation .

\section{CONCLUSIONS}

Dielectric-barrier discharges have ideal properties for establishing non-equilibrium plasma conditions in high pressure gases in a controllable way. Operation close to atmospheric pressure is an absolute necessity when large combustion flue gas streams or large mass flows have to be treated and when the reaction kinetics requires high pressure operation. Also the handling and DBD treatment of large parts is facilitated at atmospheric pressure. The properties of individual microdischarges can be tailored to suit a given application. In the microdischarges transient electron energies can be obtained that are comparable to those of low pressure volume discharges. In many applications the free radicals generated by electronic collisions are more important than the electrons and ions themselves. Free radical chemistry at atmospheric pressure is extremely fast and thus allows high production or destruction rates as well as high speed treatment of surfaces. The novel applications described in this paper were brought about by a better understanding of the discharge physics and the plasma chemistry involved on one side and on recent developments of power electronics on the other side. There is no doubt that the described industrial applications of dielectric-barrier discharges will continue to grow at a fast rate and that additional novel applications will emerge in the future.

\section{References}

[1] Siemens W., Poggendorfs Ann. Phys. Chem. 102 (1857) 66-122.

[2] Buss K., Arch. Elektrotech. 26 (1932) 261--265.

[3] Klemenc A., Hinterberger H. and Höfer H., Z. Elektrochem. 43 (1937) 261-265.

[4] Honda K. and Naito Y., J. Phys. Soc. Japan 10 (1955) 1007-1011.

[5] Gobrecht H., Meinhardt O. and Hein F., Ber. Bunsenges. phys. Chem. 68 (1964) 55-63.

[6] Bagirov M. A., N. A. Nuraliev and M. A. Kurbanov, Sov. Phys.-Tech. Phys. 17 (1972) 495-498.

[7] Tanaka M., Yagi S. and Tabata N., Trans. IEE Japan 98A (1978) 57-62.

[8] Hirth M., Beitr. Plasmaphys. 20 (1981) 1-27.

[9] Heuser C., "Zur Ozonerzeugung in elektrischen Gasentladungen", PhD Thesis, RWTH Aachen, 1985.

[10] Eliasson B., Hirth M. and Kogelschatz U., J. Phys. D: Appl: Phys., 20 (1987) 1421-1437.

[11] Eliasson B. and Kogelschatz U., Appl. Phys. B. 46 (1988) 299-303.

[12] Eliasson B. and Kogelschatz U., IEEE Trans. Plasma Sci. 19 (1991) 309-322.

[13] Eliasson B., Egli W. and Kogelschatz U., Pure \& Appl. Chem. 66 (1994), 1275-1286.

[14] Braun D., Küchler U. and Pietsch G., J. Phys. D: Appl. Phys. 24 (1991) 564-572.

[15] Braun D., Gibalov V. and Pietsch G., Plasma Sources Sci. Technol. 1 (1992) 166-172.

[16] Gentile A.C. and Kushner M.J., J. G. Appl. Phys. 79 (1996) 3877-3885.

[17] Boeuf J.-P. and Pitchford L.C., IEEE Trans. Plasma Sci. 24 (1996) 95-96.

[18] Tanaka M., Yagi S. and Tabata N., Trans. IEE of Japan, 98A (1978) 57-62.

[19] Drimal J., Gibalov V.I. and Samoilovich V.G., Czech. J. Phys. B 37 (1987) 1248-1255.

[20] Falkenstein Z. and Coogan J.J., J. Phys. D: Appl. Phys. 30 (1997) 817-825.

[21] Falkenstein Z., J, Appl. Phys. 81 (1997) 5975-5979.

[22] Kogelschatz U, "Advanced Ozone Generation" in: Process Technologies for Water Treatment S. Stucki Ed. (Plenum Press, New York,1988) pp.87-120.

[23] Müller S. and Zahn R.-J., Contrib. Plasma Phys. 36 (1996), 6, 697 - 709.

[24] Manley T.C., Trans. Electrochem. Soc. 84 (1943) 83-96.

[25] Tanaka M., Yagi S. and Tabata N., "High frequency silent discharge and its application to cw $\mathrm{CO}_{2}$ laser application", Gas Discharges and their Applications (GD 85), Oxford 1985 (Leeds University Press) pp. 551 - 554.

[26] Tamida T., Iwata A. and Tanaka M., "Characteristics and modeling of discharge in ac plasma display panels", Gas Discharges and their Applications (GD 97), Greifswald 8. - 12. September 1997.

[27] Peyrous R., "Simulation de l'évolution temporelle de diverses espèces gazeuses créées par l'impact d'une impulsion electronique dans de l'oxygène ou de l'air, sec ou humide", Dissertation, Université de Pau (France) 1986.

[28] Peyrous R., Pignolet P. and Held B., J. Phys. D.: Appl. Phys. 22 (1989) 1658-1667. 
[29] Eliasson B., Simon F. G. and Egli W., "Hydrogenation of $\mathrm{CO}_{2}$ in a silent discharge" in Non-Thermal Plasma Techniques for Pollution Control, NATO ASI Series, Vol. G 34, Part B, Non-Thermal Plasma Techniques for Pollution Control, B.M. Penetrante and S.E. Schultheis Eds. (Springer, Berlin, 1993) pp. 321-338.

[30] Kline L.E. and Siambis J. G., Phys. Rev. A5 (1972) $794-805$.

[31] Lozanskii E.D., Sov. Phys. - Tech. Phys. 13 (1969) 1269-1272.

[32] Lozanskii E.D., Sov. Phys. - Usp. 18 (1976) 893-908.

[33] Gallimberti I., J. Phys. D: Appl. Phys. 5 (1972) 2179-2189.

[34] Kunhardt E.E. and Byszewski W.W., Phys. Rev. 21(1980) 2069-2077.

[35] Kunhardt E.E. and Tzeng Y., Phys. Rev. A 38 (1988) 1410-1421.

[36] Djermoune D., Samson S., Marode E. and Ségur P. "A time resolved two dimensional modelling of the electrical behaviour and the chemical yield of streamer induced discharge", Gas Discherges and Their Applications (GD 95), Tokyo 11 - 15 September 1995, pp.II-484 - II-487.

[37] Dhali S.K. and Williams P.F., Phys. Rev A31(1987) 1219-1221.

[38] Dhali S. and Williams P.F., J. Appl. Phys. 62 (1987) 4696-4707.

[39] Yoshida K. and Tagashira H., I. Phys. D: Appl. Phys. 12 (1979) L3-L7.

[40] Kulikovsky A.A., J. Phys. D.: Appl. Phys. 27 (1994) 2556-2569.

[41] Babaeva N.Yu. and Naidis G.V., J. Phys. D.: Appl. Phys. 29 (1996) 2423-2431.

[42] Morrow R., Phys. Rev, A 35(1987) 1778-1785.

[43] Morrow R. and Lowke J.J., Austr. J. Phys. 48 (1995) 453-460.

[44] Morrow R. and Lowke J.J., J. Phys. D.: Appl. Phys. 30 (1997) 614-627.

[45] Vitello P.A., Penetrante B.M. and Bardsley J.N., Phys. Rev. E49 (1994) 5574-5598.

[46] Gibalov V.I., Samailovich V.G. and Filippov Yu.V., Russ. J. Phys. Chem. 55 (1981) 471-479.

[47] Egli W. and Eliasson B., Helv. Phys. Acta 62 (1989) 302-305.

[48] Eliasson B. and Egli W., "The silent discharge: numerical simulation of microdischarge formation", Phenomena in Ionized Gases (ICPIG XIX), Belgrade, July 1989, pp. 1024-1025.

[49] Pietsch G.J., Braun D. and Gibalov V. I., "Modeling of dielectric barrier discharges", NATO ASI Series, Vol. G 34, Part A, Non-Thermal Plasma Techniques for Pollution Control, B.M. Penetrante and S.E. Schultheis Eds. (Springer, Berlin, 1993) pp. 273-286.

[50] Pietsch G.J., J. Adv. Oxid. Technol. 1(1996) 1 61-66.

[51] Gentile A.C., "Kinetic Processes and Plasma Remediation of Toxic Gases" PhD Thesis, University of Illinois at UrbanaChampaign, 1995.

[52] Kogelschatz U. and Eliasson B. "Ozone Generation and Applications" in Handbook of Electrostatic Processes, J.S. Chang, A.J. Kelly and J.M. Crowley Eds. (Marcel Dekker, New York 1995) pp. 581-605.

[53] Filippov Yu.V., Boblikova V.A. and Panteleev V.I., Electrosynthesis of Ozone (Russ.), (Moscow State University 1987).

[54] Samoilovich V.G., Gibalov V.I. and Kozlov K.V., Physical Chemistry of the Barrier Discharge (Russ.), (Moscow State University, 1989).

[55] Kogelschatz U., "Ozone synthesis in gas discharges", Phenomena in Ionized Gases (ICPIG XVI), Düsseldorf, Aug. 1983, W. Bötticher, H. Wenk and E. Schulz-Gulde, Eds., Invited Papers, pp.240-250.

[56] Eliasson B. and Kogelschatz U., IEEE Trans. Plasma Sci. 19 (1991) 1063-1077.

[57] Kogelschatz U., "Silent discharges and their applications", Gas Discharges and Their Applications (GD92), Swansea 1318 September 1992, W.T. Williams Ed. Vol. II p. $972-980$.

[58] Eliasson B., Kogelschatz U. and Baessler P., J. Phys. B: At. Mol. Phys. 17 (1984) L797-L801.

[59] Yagi S. and Tanaka M., J. Phys. D.: Appl. Phys. 12 (1979) 1509-1520.

[60] Bonnet J., Fournier G., Pigache D. and Lécuiller M., J. Phys. Lettr. France 41 (1980)L477-L478.

[61] Penkin N.P., Smirnov V.V., and Tsygir, O.D., Sov. Phys. - Techn. Phys. 27 (1982) 945-949

[62] Rutscher A. and Wagner H.E., Beitr. Plasmaphys. 25 (1985) 336-350.

[63] Eliasson B. and Kogelschatz U., J. Chim. Phys. France 83 (1986) 279-282.

[64] Yoshida K. and Tagashira H., Mem. Kitami Inst. Technol. 18 (1986) 11-20.

[65] Okazaki S., Sugimitsu H., Niwa H., Kogoma M., Moriwaki T., and Inomata, T., Ozone Sci. \& Eng. 10 (1988) $137-151$.

[66] Nilsson J.O. "Numerical modeling of pulsed volume discharges for the generation of ozone", PhD Thesis, Royal Institute of Technology, Stockholm, 1997.

[67] Samoilovich V.G and Gibalov V.I., Russ. J, Phys. Chem. 60 (1986) 1107-1116.

[68] Kogelschatz U. and Baessler P., Ozone Sci. \& Eng. 9 (1987) 195-206.

[69] Braun D., Küchler U. and Pietsch G., Pure \& Appl. Chem. 60 (1988) 741-746.

[70] Yagi S., Tanaka M:, and Tabata N., Trans. IEE of Japan 97A (1977) 609-616.

[71] Kogelschatz U., Pure \& Appl. Chem. 62 (1990) 1667-1674.

[72] Eliasson B. and Gellert B., J.Appl.Phys. 68 (1990) 2026-2037.

[73] Kogelschatz U. "Excitation of excimer radiation in silent discharges", Phenomena in Ionized Gases (ICPIG-XX), Barga Italy 8-12 July 1991, Invited Papers pp. $218-227$.

[74] Gellert B. and Kogelschatz U., Appl. Phys. B 52 (1991)14-21.

[75] Neiger M. "Dielectric barrier discharges: An unusual new light source", Science \& Technology of Light Sources (LS 6), Budapest 10.8 - 3.9. 1992, L. Bartha and, F.J. Kedves, Eds. pp. 75-82.

[76] Falkenstein Z. and Coogan J.J., subm. to J. Phys. D: Appl Phys. (May 1997).

[77] Okabe H., Photochemistry of small molecules (J. Wiley \& Sons, New York, 1978), p. 36.

[78] Werner C. W. "Radiative and kinetic mechanisms in bound-free excimer systems", Ph D Thesis, MIT, 1975.

[79] Rhodes Ch.K. Ed., Excimer Lasers (Springer, New York, 1979).

[80] Eckstrom D.J., Nakano H.H., Lorents D.C., Rothem T., Betts J.A., Lainhart M.E., Dakin D.A. and Maenchen J.E., J. Appl. Phys. 64 (1988) 1679-1690.

[81] Zhang J.-Y. and Boyd.I.W., J. Appl. Phys. 80 (1996) 633-638. 
[82] Esrom H. and Kogelschatz U., Appl. Surf. Sci. 54 (1992) 440-444.

[83] Bergonzo P., Patel P., Boyd I.W. and Kogelschatz U., Appl. Surf. Sci. 54 (1992) 427-429.

[84] Boyd I. W. and Zhang J.-Y.,Nucl. Instr. B121 (1997) 349-356.

[85] Kogelschatz U., Eliasson B. and Esrom H., Materials \& Design 12 (1992) 251-258.

[86] Esrom H., Demny J, and Kogelschatz U., Chemtronics 4 (1989) 202-208.

[87] Kogelschatz U., Appl. Surf. Sci. 54 (1992) 410-423.

[88] Zhang J.Y. "Photochemische Modifizierung von Oberflächen durch Excimer-UV-Strahlung", PhD Thesis, University Karlsruhe, 1993.

[89] Esrom H. and Kogelschatz U., Thin Solid Films 218 (1992) 231-246.

[90] Esrom H. and Kogelschatz U., Mat. Res. Soc. Symp. Proc. 158 (1990) 189-198.

[91] Esrom H. and Kogelschatz U., Appl. Surf. Sci. 46 (1990) 158-162.

[92] Zhang J.-Y., H. Esrom H. and Boyd I.W., Appl. Surface Sci. 96-98 (1996) 399-404.

[93] Bergonzo P., Kogelschatz U. and Boyd I.W., Appl. Surf. Sci. 69 (1993) 393-397.

[94] Bergonzo P. and Boyd I.W., J. Appl. Phys. 76 (1994) 4372-4376.

[95] Bergonzo P. and I. W. Boyd I. W., Appl. Phys. Lett. 63 (1993) 1757-1759.

[96] Bergonzo P., New Applications of excimer lamps to the low temperature photo-decomposition of thin films, Ph D Thesis, University College London, 1994.

[97] Van de Leest, R.E., Appl. Surf. Sci. 86(1995), 278 - 285.

[98] Zhang J.-Y., Bie L.-J., Boyd I.W. and Dusastre V., "Thin tantalum oxide films prepared by $172 \mathrm{~nm}$ excimer lamp irradiation using sol-gel method", E-MRS Spring Meeting, Strasbourg, 16-20 June 1997, Paper B-VII.3.

[99] Zhang J.-Y. and Boyd I.W., Electronic Lett. 33 (1997) 911 -912.

[100] Kessler F. and Bauer G.H., Appl. Surf. Sci. 54 (1992) 430-434.

[101] Manfredotti C., Fizzotti F., Boero M. and Piatti G., Appl. Surf. Sci. 69 (1993) 127-132.

[102] Manfredotti C., Fizzotti F., Osenga C., Amato G. and Boarino L., Phys. Stat. Sol. (a) 135 (1993) 191-198.

[103] Esrom H., Zhang J.-Y. and Kogelschatz U., Mat. Res. Proc. 236 (1992) 39-45.

[104] Zhang, J.-Y. and Boyd I.W., Surf. Interf. Anal. 24 (1996) 718-722.

[105] Zhang J.-Y., Esrom H., Emig G. and Kogelschatz U., Modification of polymers with UV excimer radiation from lasers and lamps in Polymer Surface Modification: Relevance to Adhesion, K. L. Mittal Ed. (VSP International Science Publishers, Utrecht, The Netherlands, 1996) pp. 153-185.

[106] Esrom H., Zhang J.-Y. and Kogelschatz U., Photochemical modification and etching of PTFE with excimer VUV/UV radiation in Polymer Surfaces and Interfaces: Charaterization, Modification and Application, K.L.Mittal and K.-W. Lee Eds. (VSP International Science Publishers, The Netherlands, 1996) pp 27-35.

[107] Heitz J., Niino H. and Yabe A., Appl. Phys. Lett. 68 (1966) 2648-2650.

[108] Habibi S., Totsuka M., Tanaka J., Kinoshita T. and Matsumoto S., J. Vac. Sci. Technol. B 13 (1995) 247-252.

[109] Boyd I.W. and Zhang J.-Y., "Low temperature Si oxidation with excimer lamp sources", Invited Paper, MRS Spring Meeting, San Francisco, April 1997.

[110] Kogelschatz U., "UV production in dielectric barrier disctrrges for pollution control", ASI Series, Vol. G 34, Part B, Non-Thermal Plasma Techniques for Pollution Control, B.M. Penetrante and S.E. Schultheis Eds. (Springer, Berlin, 1993) pp. $339-354$.

[111] Loraine G. A. and Glaze W. H., "Destruction of vapor phase halogenated methanes by means of ultraviolet photolysis", 47th Purdue Industrial Wasste Conference (Lewis Publishers, Inc. Chelsea, Michigan, U. S. A. 1992) pp. 309-316.

[112] Scheytt H. "Untersuchungen zur UV-photoinduzierten Oxidation chlorierter Kohlenwasserstoffe in der Gasphase", Ph D Thesis, University of Erlangen, 1995.

[113] Scheytt H., Esrom H., Prager L., Mehnert R. and von Sonntag C., Ultraviolet light and electron beam induced degradation of trichloroethylene, NATO ASI Series, Vol. G 34, Part B, Non-Thermal Plasma Techniques for Pollution Control, B.M. Penetrante and S.E. Schultheis Eds. (Springer, Berlin, 1993) pp. 91-102.

[114] Jakob L., Traitement des eaux par photocatalyse et photolyse V-UV: Degradation oxydative de polluants organiques, PhD Thesis, Ecole Polytechnique Fédéral de Lausanne, Switzerland, 1992.

[115] Jacob L., Hashem T.M., Bürki S., Guindy N.M. and Braun A.M., J. Photochem. Photobiol. A: Chem. 75 (1993) 97-113.

[116] Loraine G.A., Hazard. Waste \& Hazard. Mater. 10 (1993), 185-194.

[117] Nohr R.S., MacDonald J.G., Kogelschatz U., Mark G., Schuchmann H.-P. and von Sonntag C., J. Photochem. Photobiol. A: Chem. 79 (1994) 141-149.

[118] Oppenländer T., Europ. Photochem. Ass.Newslett., 50 (1994) 2-8.

[119] Legrini O., Oliveros E. and Braun A.M., Chem. Rev. 93 (1993) 671-698.

[120] Oppenländer T., Baum G., Egle W. and Hennig T., Indian Acad. Sci. (Chem. Sci.) 107 (1995) 621-636.

[121] Baum, G. and Oppenlaender T., Chemosphere 30 (1995) 1781-1790.

[122] Beneking C.,Dannert H.,Neiger M., Schorpp V., Stockwald K. and Müller H. "Neuartige UV-Lampen auf der Basis stiller Entladungen", BMFT (Bundesministerium für Forschung und Technologie) Forschungsbericht FKZ 12N5695, 1992.

[123] Urakabe T., Harada S., Saikatsu T. and Karino M. "A flat fluorescent lamp. with dielectric barrier discharges", Science and Technology of Light Sources (LS 7), Kyoto, 27-31 August 1995, R. Italani and S. Kamiya Eds. (The Illuminating Engineering Institute of Japan, 1995) pp. 159-160.

[124] Sobel A., IEEE Trans. Plasma Sci. 19 (1991) 1032-1047.

[125] Boeuf J.-P. and Doyeaux H., Europhys. News 27 (1996) 46-49.

[126] Mikoshiba S., Informations Display 10 (1994) 21-23.

[127] Mikoshiba S., "Color Plasma Displays", SID International Symposium, Boston 12-16 May 1997, Seminar Lecture Notes, J. Morreale Ed., Vol. 1, pp. M-4/1 - M-4/36.

[128] Meunier J., Belenguer Ph. and Boeuf J.P., J. Appl. Phys. 78 (1995) 731-745.

[129] Meunier J., Etude numérique et experimentale d'une cellule de panneau à plasma alternatif couleur, Thèse No. 1014, C.P.A.T. Toulouse, 1995. 
[130] Veerasingam R., Campbell R.C. and McGrath R.T., IEEE Trans Plasma Sci. 23 (1995) 688-697.

[131] Boeuf J.-P. and Pitchford L.C., IEEE Trans. Plasma Sci. 24 (1996) 95-96.

[132] Campbell R.C., Veerasingam R. and McGrath R.T., IEEE Trans. Plasma Sci. 23 (1995) 698-708.

[133] Ishchenko V.N., Lisitsyn V.N. and Sorokin A. R., Sov. J. Quant. Electron. 8 (1978) 453-457.

[134] Christensen, C.P., Appl. Phys. Lett. 34 (1979) $211-213$.

[135] Yagi, S. and Tabata N., IEEE/OSA Conf. on Lasers and Opto-Electronics, Washington DC 1989, Paper WE5,22.

[136] Tanaka M., Yagi S. and Tabata N., "High frequency silent discharge and its application to $\mathrm{cw}^{\mathrm{CO}} \mathrm{O}_{2}$ laser application", Gas Discharges and their Applications (GD 85), Oxford 1985 (Leeds University Press) pp. 551-554.

[137] Yasui K., Kuzumoto M., Ogawa S., Tanaka M. and Yagi S., IEEE J. Quantum Electron. 25 (1989) 836-840.

[138] Takenaka Y., Kuzumoto M., Yasui K., Yagi S. and Tagashira M., IEEE J. Quantum Electron. 27 (1991) $2482-2487$.

[139] Clothiaux E. J., Koropchak J. A. and Moore R.R., Plasma Chem. \& Plasma Proc. 4 (1984) 15-20.

[140] Fraser, M.E. and R. Sheinson R., Plasma Chem. \& Plasma Proc. 6 (1986) 27-38.

[141] Penetrante B.M. and Schultheis S.E. Eds., "Non-Thermal Plasma Techniques for Pollution Control", NATO ASI Series G: Ecological Sciences Vol. 34A, and B (Springer, Berlin. 1993).

[142] Rosocha L. A., Processing of hazardous chemicals using silent-discharge plasmas in Plasma Science and the Environment, W. Manheimer, L.E. Sugiyama and T.H. Stix Eds. (American Institute of Physics, Woodbury, New York, 1997) pp. 261-298.

[143] Comes F.J., Angew. Chem. 106 (1994) 1900-1910.

[144] Sardja, I. and Dhali S. K., Appl. Phys. Lett. 56 (1990) 21-23.

[145] Dhali, S.K. and Sardja I., J. Appl. Phys. 69 (1991) 6319-6324.

[146] Chang M.B., Balbach J.H., Rood M. J. and Kushner M.J., J. Appl, Phys. 69 (1991) 4409-4417.

[147] Chang M.B., Kushner M.J. and Rood M.J., Plasma Chem. \& Plasma Proc. 12 (1992) 565-580.

[148] Chang M.B., Kushner M.J. and Rood M.J., Environ. Sci. Technol. 26 (1992) 777-781.

[149] Chang M.B., Kushner M.J. and Rood M.J., J. Environm. Eng. 119 (1993) 414-423.

[150] Higashi M., Uchida S., Suzuki N. and Fujii K., IEEE Trans. Plasma Sci. 20 (1992) 1-12.

[151] Gentile A.C. and Kushner M.J., J. Appl. Phys. 78 (1995) 2074-2085.

[152] Storch D.G. and M. J. Kushner M.J., J. Appl. Phys. 53 (1993) 51-55.

[153] Neely. W.C. , Newhouse E.I., Clothiaux E.J. and Gross C.A., Decomposition of complex molecules using silent discharge processing, NATO ASI Series, Vol. G 34, Part B, Non-Thermal Plasma Techniques for Pollution Control, B.M. Penetrante and S.E. Schultheis Eds. (Springer, Berlin, 1993) pp. 309-320.

[154] Evans D., Rosocha L.A., Anderson G.K., Coogan J.J. and Kushner M.J., J. Appl. Phys. 74 (1993) 5378-5386.

[155] Hsiao M.C., Merrit B.T., Penetrante B.M. and Vogtlin G.E., J. Appl. Phys. 78 (1995) 3451-3456.

[156] Bugaev S.P., Kushinov V.A., Sochugov N.S. and Khryapov P.A., Plasma Chein. \& Plasma Process. 16 (1996) $669-677$.

[157] Falkenstein Z., J. Adv. Oxid, Technol. 1(1997) 3 1-16.

[158] Traus I. and Suhr H., Plasma Chem. \& Plasma Proc. 12 (1992) 275-285.

[159] Chang M.B. and Tseng T. D., J. Environm. Eng. 122 (1996) 41-46.

[160] Falkenstein, Z., Fundamental Studies on the Combined (V)UV-Non-Thermal Plasma Treatment of Air Pollutants, Ph D Thesis, University of Karlsruhe 1996 (Los Alamos Report LAUR-96-2219).

[161] Chang J.-S., Lawless P. A. and Yamamoto T., IEEE Trans. Plasma Sci. 19 (1991) 1152-1166

[162] Nunez C.M., Ramsey G.H., Ponder W.H., Abbott J.H., Mammel L.E. and Kariher P.H., Air \& Waste 43 (1993) $242-247$.

[163] Linsley Hood J.L., "The corona treatment of plastic films", Gas Discharges and Their Applications (GD 80), Edinburgh 8-11 September 1980, pp.86-90.

[164] Donohoe K.G. and Wydeven T., "Plasma polymerisation of ethylene in an atmospheric pressure discharge", Plasma Chemistry (ISPC-4), Zürich 27. August - 1. September 1979, S. Veprek and J. Hertz, Eds., pp. 765-771.

[165] Kanazawa S., Kogoma M., Moriwaki T. and Okazaki S., J. Phys. D: Appl. Phys. 21 (1988) 838-840.

[166] Yokoyama T., Kogoma M., Kanazawa S., Moriwaki T. and Okazaki S., J. Phys. D: Appl. Phys. 23 (1990) $374-377$.

[167] Okazaki S., Kogoma M., Uehare M. and Kimura Y., J. Phys. D.:Appl. Phys. 26 (1993) 889-892.

[168] Kogoma M. and Okazaki S., J. Phys. D.:Appl. Phys. 27 (1994) 1985-1987.

[169] Massines F., Mayoux C., Messaoudi R., Rabehi A. and Ségur P., Gas Discharges and Their Applications (GD 92), Swansea 13-18 September 1992, W. T. Williams Ed., Vol II, pp 730-733.

[170] Massines F., Gadri R.B., Decomps P., Rabehi A., Ségur P. and Mayoux C. “Atmospheric pressure dielectric controlled glow discharges: diagnostics and modelling”, Phenomena in Ionized Gases (XXII ICPIG), 31 July -4 August, Hoboken, NJ 1995, K.H.Becker, W.E.Carr and E.E. Kunhardt Eds. (AIP Press Woodbury, N. Y., 1996, Conference Proceedings 363) Invited Papers pp. 306-315.

[171] Reitz U., Barrierententladungen zur plasmagestützten Oberflächenbehandlung, PhD Thesis, TU Braunschweig, 1992.

[172] Schwarz R., Über die Beschichtung von Oberflächen mit Barrierenentladungen bei Atmosphärendruck, PhD Thesis, Technical University Braunschweig 1995.

[173] Salge J., Surf. Coat. Technol. 80 (1996) 1-7.

[174] Meiners S., Salge J.G.H., Prinz E. and Förster F. "Surface modification of polymer materials by transient gas discharges at atmospheric pressure", Plasma Surface Engineering, Garmisch-Partenkirchen 9-13 September 1996.

[175] Eliasson B., $\mathrm{CO}_{2}$ Chemistry: An Option for $\mathrm{CO}_{2}$ Emission Control ? in Carbon Dioxide Chemistry: Environmental Issues, J. Paul and C.-M. Pradier Eds. (The Royal Society of Chemistry, Cambridge, G.B., 1994) pp. 5-15.

[176] Bill A., Wokaun A., Eliasson B., Killer E. and Kogelschatz U., Energy Convers. Mgnit. 38 (1997) S415- S422.

[177] Okazaki K., Nozaki T., Uemitsu Y. and Hijikata K., "Direct conversion from methane to methanol by a pulsed silent discharge plasma", Plasma Chemistry (ISPC-12), Minneapolis, Aug. 21-25, 1995, J.V.Heberlein, D.W.Ernie and J.T.Roberts Eds. (University of Minnesota) Vol. II, 581-586.

[178] Shepelev S.S., Gesser H.D. and Hunter N.R., Plasma Chem. \& Plasma Proc. 13 (1993) 479-488.

[179] Eliasson B., Kogelschatz U., Xue B. and Zhou L.M." "Application of dielectric barrier discharges to the decomposition and utilisation of greenhouse gases", Plasma Chemistry (ISPC-13), Beijing, Aug. 18 - 22, 1997, C.K.Wu Ed. (Peking University Press) Vol. IV, 1784-1789. 